\title{
Kewajiban Adanya Kepemimpinan Politik dalam Perspektif Fikih
}

\author{
Yasin Muthohar ${ }^{1}$ \\ ${ }_{1}^{1}$ Pesantren Al Abqory, Banten, Indonesia
}

ARTICLE INFO ABSTRACT

\section{Keywords}

Islam, Politik, Khilafah,

Fikih Islam

\section{*Correspondence ymuthahhar@gmail.com}

\section{Article History}

Received 1 April 2018

Accepted 28 April 2018

Published on-line 10 May

2018

\begin{abstract}
Islam merupakan Din ${ }^{1}$ yang Allah turunkan mengatur segala aspek kehidupan manusia, dengan seperangkat aturan yang agung dan paripurna, mencakup perkara akidah maupun hukum syari'ah. Penelitian ini dilakukan secara deskriptif dan disusun dengan maksud untuk mengkaji fakta politik Rasulullan dan Khulafaurrasyidin, bagaimana islam yang merupakan sebuah kepemimpinan yang harus ditegakkan. Oleh karena itu, dapat kita saksikan bahwa Khilafah, terang benderang sebagai bagian dari ajaran Islam yang mulia, memuliakan mereka yang mengemban dan memperjuangkannya seterang mentari terbit tak terhalang awan bagi ia yang teguh meniti jalan Rasul-Nya. Secara praktis, penegakan konsep khas kepemimpinan Islam ini sebagaimana ditunjukkan oleh sunnah Rasulullah Saw, yang menegakkan institusi politik Islam berpusat di Madinah al-Munawwarah, diteruskan oleh para sahabat al-khulafấ' al-râsyidûn pada periode yang disebut Rasulullah Saw dalam hadits hasan riwayat Imam Ahmad, sebagai periode al-khilâfah 'alâ minhâj al-nubuwwah. Ditegaskan para ulama dalam turats mereka yang menguraikan kewajiban menegakkan institusi Khilafah ini dalam kehidupan, sebagai ajaran Rasulullah Saw dan disepakati para sahabat dengan konsensus (ijma') mereka
\end{abstract}

\section{PENDAHULUAN}

Islam merupakan Din $^{2}$ yang Allah turunkan mengatur segala aspek kehidupan manusia, dengan seperangkat aturan yang agung dan paripurna, mencakup perkara akidah maupun hukum syari'ah, dari mulai persoalan pribadi, hingga persoalan kompleks tata kelola kehidupan bernegara. Islam, sebagaimana ditunjuki nas-nas al-Qur'an dan al-Sunnah, diuraikan secara mapan oleh para ulama, salah satunya Al-'Allamah al-Syaikh Taqiyuddin al-Nabhani (w. 1396 H) dalam Nizhâm al-Islâm:

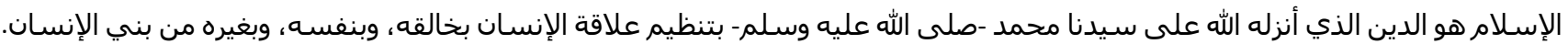

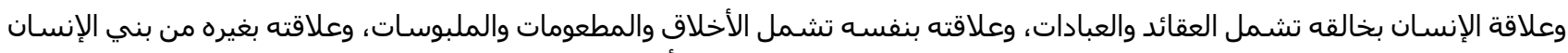

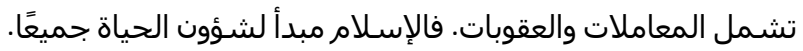

Islam adalah din yang Allah turunkan kepada Sayyidina Muhammad SAW, untuk mengatur hubungan antara manusia dengan Pencipta-Nya, dirinya sendiri dan sesama manusia. Hubungan manusia dan Pencipta-Nya mencakup akidah dan peribadahanperibadahan; hubungan manusia dengan dirinya sendiri mencakup akhlak, makanan dan pakaian; hubungan manusia dengan sesama manusia mencakup mu'amalah, dan hukum-hukum persanksian. Maka Islam adalah ideologi yang mengatur seluruh aspek kehidupan. ${ }^{3}$

Ruang lingkup Din Islam dalam pengertian yang diuraikan oleh al-'Allamah Taqiyuddin al-Nabhani: Pertama, Mengatur hubungan manusia dan Pencipta-Nya mencakup akidah dan peribadahan-peribadahan; Kedua, Mengatur hubungan manusia dengan dirinya sendiri mencakup akhlak, makanan dan pakaian; Ketiga, Mengatur hubungan manusia dengan sesama manusia mencakup mu'amalah, dan hukum-hukum persanksian.

Inti penjelasan senada dipaparkan oleh Prof. Dr. Muhammad Rawwas Qal'ah Ji (w. 1435 H), bahwa Islam adalah Din yang Allah turunkan kepada Nabi Muhammad Saw mencakup akidah, syari'ah dan akhlak. ${ }^{4}$ Hal ini menunjukkan bahwa Allah Swt

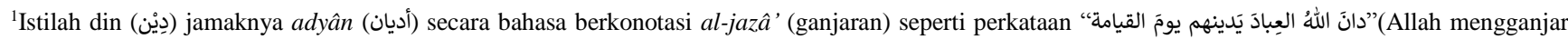

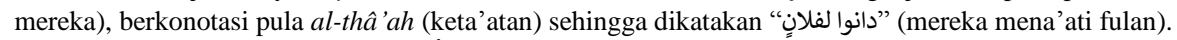

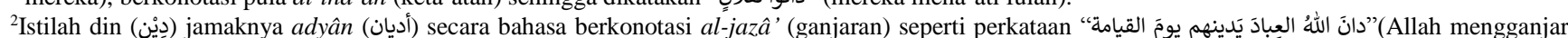
mereka), berkonotasi pula al-thâ'ah (keta'atan) sehingga dikatakan "دوانِ (mereka mena'ati fulan).

${ }^{3}$ Al-Qadhi Taqiyuddin bin Ibrahim, Nizhâm Al-Islâm, Beirut: Dar al-Ummah, 1953, hlm. 34.

${ }^{4}$ Prof. Dr. Muhammad Rawwas Qal'ah Ji dkk, Mu’jam Lughat al-Fuqahâ', Beirut: Dâr al-Nafâ'is, cet. II, 1408 H/1988, juz I, hlm. 68.
} 
JKPIs, Vol. 1 No. 1, 2018 | 36 menciptakan manusia, berikut seperangkat petunjuk, pedoman lengkap nan paripurna sebagai bekal mengarungi medan kehidupan.

Kesempurnaan Din Islam ini ditunjukkan oleh nas-nas syara', di antaranya:

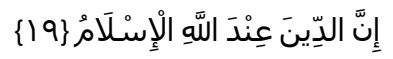

“Sesungguhnya agama (yang diridhai) di sisi Allah hanyalah Islam.” (QS. Ali Imrân [3]: 19).

Ayat ini menjelaskan kedudukan Islam sebagai agama samawi yang diturunkan oleh Allah kepada manusia. Namun ketika Allah menjelaskan "sesungguhnya agama di sisi Allah hanyalah Islam" berarti bahwa agama lain tidak sah dan tidak diakui-Nya. Pengertian ini dikuatkan oleh firman Allah Swt:

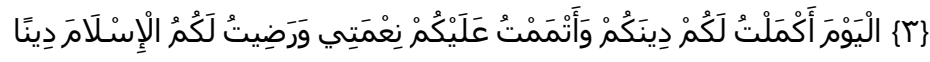

"Hari ini telah Aku sempurnakan untuk kamu agama kamu, dan telah Aku cukupkan untuk kamu nikmat-Ku, serta Aku ridhai Islam sebagai agama kamu." (QS. Al-Mâidah [5]: 3).

Ayat ini menjelaskan, bahwa hanya Islam satu-satunya agama yang diridhai oleh Allah Swt, sementara yang lain tidak. Ini bisa dipahami dari mafhûm mukhâlafah lafal: "Aku ridhai" yang merupakan kata kerja sifat: "Aku ridhai Islam sebagai agama kamu" yang berarti pula: "Aku tidak meridhai selain Islam sebagai agama kamu." Mafhûm ini diperkuat oleh nas berikut ini:

$$
\text { وَمَنْ يَبْتَغ غَيْرَ الْإِسْلَامِ دِينًا فَلَنْ يُقْبَلَ مِنْهُ وَهُوَ فِي الْآخِرَةِ مِنَ الْخَاسِرِينَ }\{\Lambda 0\}
$$

"Siapa saja yang mencari selain Islam sebagai agama, sekali-kali tidak akan diterima (agama itu) darinya, dan di akhirat dia termasuk orang-orang yang merugi." (QS. Ali Imrân [3]: 85).

Dalam ayat ini, terdapat kecaman keras bagi siapa saja yang mencari selain ajaran Islam sebagai panduan hidupnya. Ungkapan "selain Islam" yang dimaksud dalam ayat ini umum, ditunjukkan oleh lafal din[an] dalam bentuk lafal nakirah yang berfaidah ta'mîm, mencakup seluruh ajaran yang bertentangan dengan Islam, apakah berupa agama kufur seperti: Yahudi, Nasrani, Budha, Hindu dan lain sebagainya, juga ideologi kufur seperti Komunisme dan Kapitalisme, termasuk ajaran-ajaran kufur Barat seperti Liberalisme, Sekularisme dan Demokrasi. Menafsirkan ayat ini, al-Hafizh Ibn Jarir al-Thabari (w. 310 H) menegaskan yakni, "Siapa saja yang mencari ajaran selain Din Islam untuk dilaksanakan, maka Allah tidak akan menerimanya."

Keumuman cakupan ini relevan dengan prinsip bahwa Islam merupakan ajaran yang lengkap dan sempurna, tak membutuhkan tambahan dan pengganti. Kesempurnaan dan kelengkapan Din Islam ini pun, sejalan dengan prinsip bahwa Allah Swt telah menurunkan al-Qur'an sebagai pedoman hidup manusia sebagaimana firman-Nya:

$$
\text { \{ } 9\}
$$

"Dan Kami turunkan kepadamu Al-Kitab (Al-Qur'an) sebagai penjelasan atas segala sesuatu, petunjuk dan rahmat serta kabar gembira bagi orang-orang yang berserah diri." (QS. Al-Nahl [16]: 89).

Makna frase (تبيانًا لكل شيء) adalah "sebagai penjelasan atas apa-apa yang dibutuhkan oleh umat"; mengetahui halal haram, pahala dan siksa, hukum-hukum serta dalil-dalil, sebagaimana dijelaskan oleh al-Hafizh Ibn Jarir al-Thabari (w. 310 H) ${ }^{5}$, Imam alTsa'labi6, Imam Abu Bakr al-Jazairi ${ }^{7}$ dan para ulama lainnya dalam kitab-kitab tafsir al-Qur'an. Abu Bakar al-Jazairi menjelaskan bahwa kedudukan al-Qur'an sebagai hud[an] yakni petunjuk dari segala kesesatan, dan rahmat[an] yakni rahmat khususnya bagi mereka yang mengamalkan dan menerapkannya bagi diri sendiri dan di dalam kehidupan sehingga rahmat tersebut bersifat umum di antara mereka. ${ }^{8}$

Seluruh penjelasan di atas, menunjukkan adanya konsep politik dalam Islam, yakni konsep pengaturan Islam atas kehidupan bermasyarakat dan bernegara, tak dapat dipisahkan, negara wajib menegakkan syari'at Islam dalam kehidupan.

\section{KAJIAN FAKTA POLITIK ZAMAN RASULULLAH DAN KHULAFAURRASYIDIN}

Siapa saja yang menelaah kehidupan Rasulullah SAW dia akan menyimpulkan bahwa beliau bukan hanya seorang nabi dan Rasul. Lebih dari itu beliau SAW adalah seorang kepala negara. Karena itu, "Daulah Islamiyah" merupakan realitas empirik pada masa Rasulullah saw dan Sahabat. Terdapat dalil-dalil sharih yang menunjukkan, bahwa Rasulullah saw telah membangun struktur Daulah Islamiyyah di Madinah.

Riwayat-riwayat mutawatir dan terpercaya telah memberikan informasi akurat mengenai bentuk dan stuktur negara yang dibangun Rasulullah saw. Apa yang dilakukan oleh Rasulullah saw di Madinah menunjukkan, bahwa beliau saw membangun negara, melakukan aktivitas kenegaraan, serta meletakkan landasan teoritis bagi bentuk dan sistem pemerintahan yang maju. Bahkan, di kemudian hari, sistem pemerintahan Islam, baik yang menyangkut aspek kelembagaan maupun hukum banyak diadopsi

\footnotetext{
${ }^{5}$ Muhammad bin Jarîr bin Yazîd bin Katsîr Abu Ja'far al-Thabari, Jâmi’ al-Bayân fì Ta 'wîl al-Qur'ân, juz XVII, hlm. 278.

${ }^{6}$ Ahmad bin Muhammad bin Ibrahim al-Tsa'labi, Al-Kasyf wa al-Bayân 'an Tafsîr al-Qur'ân, Beirut: Dâr Ihyâ' at-Turâts al-'Arabi, Cet. I, 1422 H, jilid VI, hlm. 37

${ }^{7}$ Jabir bin Musa bin 'Abdul Qadir bin Jabir Abu Bakr Al-Jaza'iri, Aysar at-Tafâsîr li Kalâm al- 'Ulya al-Kabîr, Madinah: Maktabah al-'Ulûm wa al-Hikam, Cet. V, 1424 H, jilid III, hlm. 138-139.

${ }^{8}$ Ibid.
} 
JKPIs, Vol. 1 No. 1, 2018 | 37

dan menjadi dasar bagi sistem pemerintahan modern. Meskipun di masa Rasulullah saw sistem dan struktur kenegaraan belum dilembagakan dalam sebuah buku khusus, namun, praktek kenegaraan yang dilakukan oleh Rasulullah saw dan para shahabat adalah perwujudan nyata dari sistem pemerintahan Islam, yang berbeda dengan sistem pemerintahan manapun. Kenyataan ini sudah cukup untuk menangkis keraguan bahkan cibiran sebagian pihak yang meragukan eksistensi pemerintahan dan aktivitas kenegaraan yang dilakukan oleh Rasulullah saw.

Pemerintahan Islam yang dibangun oleh Rasulullah saw meliputi asas negara, struktur, perangkat, mekanisme pemerintahan, serta kelengkapan-kelengkapan administratif. Paradigma dasar pemerintahan Islam didasarkan pada prinsip, kedaulatan ada di tangan syariat dan kekuasaan ada di tangan rakyat. Kedaulatan (sovereignty) adalah daulat (kekuasaan) tertinggi untuk menetapkan hukum. Sedangkan kekuasaan ada di tangan rakyat, maksudnya adalah, kewenangan untuk mengangkat kepala negara (khalifah) ada di tangan rakyat yang disalurkan melalui sebuah mekanisme yang bernama baiat. Islam telah menggariskan, bahwa kedaulatan tertinggi untuk menetapkan hukum hanya di tangan Allah swt semata. Manusia tidak memiliki kewenangan dan hak sama sekali untuk menetapkan hukum. Ia hanya berkewajiban menurunkan hukum yang digali dari nash syariat, untuk kemudian diberlakukan pada realitas yang ada di tengah-tengah masyarakat. Namun demikian, rakyat memiliki kewenangan mengangkat salah seorang diantara mereka untuk menjadi kepala negara yang akan mengatur urusan mereka dengan syariat Islam. Bukti-bukti mengenai eksistensi Daulah Islamiyyah di masa Rasulullah saw, asas, struktur, dan mekanisme birokrasi pemerintahan dapat dijelaskan sebagai berikut.

\subsection{Dasar Negara: 'Aqidah Islamiyyah Pondasi Daulah Islamiyyah}

Rasulullah saw memerintahkan agar kaum Muslim selalu menjaga keberadaan aqidah Islam, sebagai landasan dasar bagi daulah Islam. Bahkan, beliau telah memerintahkan kepada kaum Muslim agar mengangkat senjata dan berperang bila terlihat kekufuran yang nyata, yakni bila aqidah Islam tidak lagi dijadikan sebagai landasan pemerintahan dan kekuasaan. Oleh karena itu, tatkala Rasulullah saw ditanya tentang pemerintahan yang dzalim, "Tidakkah kita perangi saja mereka itu dengan pedang (Wahai) Rasulullah? Beliau menjawab, "Jangan, selagi mereka masih menegakkan sholat (hukum Islam)". Beliau saw melarang kaum Muslim untuk mencabut bai'at dari tangan ulil amri (khalifah) kecuali kalau mereka menyaksikan kekufuran yang nyata. Imam Muslim meriwayatkan dari Auf bin Malik tentang kebobrokan para pemimpin, "Ditanyakan (kepada Rasulullah saw), "Ya Rasulullah, tidakkah kita perangi saja itu dengan pedang? Beliau menjawab," Jangan, selama mereka masih menegakkan sholat (hukum Islam)".

Imam Bukhari juga meriwayatkan dari 'Ubadah bin Shamit tentang bai'at, "Dan agar kami tidak mengambil urusan tersebut pada ahlinya, kecuali bila kalian menyaksikan kekufuran yang nyata, sedangkan kalian mempunyai bukti yang kuat (burhan) di sisi Allah." Dalam riwayat al-Thabarani, beliau menyatakan dengan kata kufran sharrahan (bukan kufran bawwahan).

Ini menunjukkan bahwa asas daulah Islam adalah aqidah Islam. Dengan landasan inilah Rasulullah saw membangun kekuasaan. Bahkan, untuk menjaga eksistensi 'aqidah Islamiyyah ini, beliau telah memerintahkan kepada kaum Muslim, agar mengangkat senjata, bila terlihat kekufuran yang nyata; yakni bila 'aqidah Islam tidak lagi dijadikan sebagai asas dasar negara.

Daulah Islamiyyah dipimpin oleh seorang khalifah yang bertugas untuk menerapkan dan menegakkan hukum Islam di dalam negeri, dan mengemban dakwah Islam ke seluruh penjuru dunia dengan dakwah dan jihad. Oleh karena itu, aturan yang diberlakukan di dalam Daulah Islamiyyah adalah aturan Islam, yang terpancar dari 'aqidah Islam, bukan aturan lain. Allah swt berfirman, artinya,

"Maka demi Tuhanmu, mereka (pada hakekatnya) tidak beriman hingga mereka menjadikan kamu sebagai hakim dalam perkara yang mereka perselisihkan." (al-Nisaa':65).

"Dan hendaklah kamu memutuskan perkara di tengah-tengah mereka menurut apa yang diturunkan Allah". (al-Maidah: 49)

"Dan barangsiapa yang tidak menerapkan hukum dengan apa yang diturunkan oleh Allah, maka mereka adalah orang-orang yang kafir." (al-Maidah:44).

Rasulullah saw bersabda,

"Setiap perbuatan yang tidak mengikuti perintahku (tuntunanku), maka perbuatan itu tertolak".

Atas dasar ini, seluruh perundang-undangan daulah Islam, baik undang-undang dasar maupun undang-undang yang lain, ditetapkan berdasarkan hukum syara' yang digali dari aqidah Islam. Yakni, hukum yang bersumber dari al-Kitab dan al-Sunnah.

\subsection{Struktur Negara Islam di Madinah}

Setelah beliau saw sampai ke Madinah beliau langsung memimpin kaum Muslim, melayani kepentingan mereka, memanaj urusanurusan mereka, membentuk masyarakat Islam, serta mengadakan perjanjian dengan orang Yahudi; baru kemudian dengan bani Dhamrah serta bani Mudlij; lalu dengan kafir Quraisy, penduduk Ailah, Jarba', dan Adzrah. Beliau mengadakan perjanjian tersebut agar mereka tidak sampai menghalang-halangi orang yang hendak menunaikan ibadah haji. Juga agar tidak ada seorangpun yang diprovokasi pada saat syahr al-haram (bulan Dzulqa'dah, Dzulhijjah, Muharram, serta Rajab). Beliau pernah mengirim Hamzah bin 'Abd al-Muthalib, Muhammad bin 'Ubaidah bin al-Harits, serta Sa'ad bin Abi Waqqas dalam sebuah detasemen untuk menyerang kaum Quraisy. Beliau mengirim Zaid bin Haritsah, Ja'fah bin Abi Thalib dan 'Abdullah bin Rawahah untuk menyerang bangsa Romawi. Beliau saw juga mengirim Khalid bin Walid untuk menyerang penduduk Dumat al-Jandal. Dalam beberapa peperangan, terkadang beliau memimpin sendiri pasukannya secara langsung. Beliau saw juga terjun langsung dengan pasukannya dalam pertempuran yang dahsyat. Baliau juga pernah mengangkat wali (semacam pimpinan daerah tingkat I) untuk daerah-daerah tertentu, serta para amil (semacam pimpinan daerah tingkat II) untuk beberapa negeri. Beliau pernah menunjuk Utab bin Usaid untuk menjadi wali di Mekah setelah kota itu ditaklukkan. Kemudian setelah masuk Islam, Badzan bin Sasan, ia diangkat menjadi wali di Yaman. Beliau juga pernah mengangkat Mu'ad bin Jabal al-Khazraji ntuk menjadi wali di Janad. Khalid bin Walid menjadi 
JKPIs, Vol. 1 No. 1, 2018 | 38

'amil di Shun'a'. Ziyad bin Lubaid bin Tsa'labah al-Anshariy menjadi wali di Hadramaut. Abu Musa al-Asy'ariy menjadi wali di Zabid dan 'Adn. 'Amr bin al-'Ash di Oman. Abu Dujanah menjadi 'amil di Madinah.

Ketika beliau menunjuk para wali tersebut, beliau memilih seseorang untuk menjadi wali atau 'amil dengan kualifikasi yang paling sempurna dalam melaksanakan tugasnya. Beliau juga senantiasa menanamkan iman dalam benak mereka yang akan diterjunkan di daerah-daerah yang telah beliau tentukan. Beliau selalu menanyai mereka tentang cara yang akan mereka pergunakan dalam menentukan keputusan mereka. Imam Baihaqi, Ahmad, dan Abu Dawud telah meriwayatkan dari Mu'adz; bahwa ketika beliau mengirim Mu'adz ke Yaman, beliau bertanya kepadanya, "

"Bagaimana caramu memutuskan, bila engkau dihadapkan pada sebuah perkara? Mu'adz menjawab, "Saya akan memutuskan dengan Kitabullah. Beliau bertanya, "Jika kamu tidak menemukannya dalam Kitabullah? Mu'adz menjawab, "Saya akan memutuskan dengan sunnah Rasul-Nya. Beliau bertanya lagi, "Jika kamu tidak menemukannya dalam sunnah Rasul-Nya? Mu'adz menjawab, "Saya akan berijtihad dengan pendapatku, dengan seluruh daya upayaku. Mu'adz mengatakan, "Beliau lalu menepukkan tangan beliau ke dadaku. Lalu beliau bersabda, "Segala puji hanya milik Allah, yang telah memberikan taufiq kepada utusan Rasulullah dengan sesuatu yang amat dicintai oleh Rasul-Nya."

Orang Yahudi dan Nashrani yang telah memeluk Islam dengan tulus dari lubuk hati mereka, maka mereka adalah orang-orang mukmin. Mereka berhak mendapatkan hak dan kewajiban sebagaimana layaknya orang mukmin yang lain. Sedang bagi mereka yang tetap dalam ke-nashraniannya dan keyahudiannya , tetap akan dilindungi. Imam Muslim dan Bukhari meriwayatkan dari Ibnu Abbas yang mengatakan, bahwa Rasulullah saw ketika mengirim Mu'adz ke Yaman, beliau bersabda, "

"Sesungguhnya kamu akan mendatangi kaum ahli kitab, maka hendaknya yang pertama kali kamu sampaikan kepada mereka adalah (agar mereka) beribadah kepada Allah 'Azza Wa Jalla. Jika mereka tidak mengenal Allah, sampaikan kepada mereka bahwa Allah memfardlukan kepada mereka shalat lima waktu dalam sehari semalam. Bila mereka melakukannya, sampaikanlah kepada mereka bahwa Allah telah memfardlukan kepada zakat kepada mereka, yang akan diambil dari mereka yang kaya, kemudian akan diberikan kepada yang miskin. Jika mereka mentaatinya, maka ambillah dari mereka, dan kehormatan hartanya pun akan dijaga"9.

Dalam riwayat yang kedua, riwayat Muslim dan Bukhari dengan tambahan, "Berhati-hatilah terhadap do'a orang-orang yang terdzalimi. Sebab antara mereka dengan Allah tidak terdapat hijab (penghalang)."

Nabi saw pernah mengangkat para qadli untuk memutuskan perkara hukum di tengah-tengah rakyat. Beliau pernah mengangkat 'Ali bin Abi Thalib sebagai qadli di Yaman dan 'Abdullah bin Naufal sebagai qadli di Madinah. Beliau juga pernah menugaskan Mu'adz bin Jabal dan Abu Musa al-Asy'ariy untuk menjadi qadli di Yaman (Yaman Utara dan Selatan). Rasul pernah menanyai keduanya, "

"Dengan apa kalian menghukumi?" Mereka berdua menjawab, "Jika kami tidak menemukannya di dalam al-Kitab dan al-Sunnah, kami akan mengqiyaskan satu masalah dengan masalah lain. Mana yang lebih mendekati kepada kebenaran, maka itulah yang akan kami pergunakan."

Dan Nabi pun membenarkannya. Sesuatu yang menunjukkan bahwa beliau senantiasa memilih para qadli serta menentukan cara mereka mengambil keputusan. Nabi saw juga mengatur seluruh kepentingan masyarakat. Beliau mengangkat para penulis untuk mengatur kepentingan tersebut. Mereka itu (para penulis) layaknya seperti dirjen sebuah departemen. Ali bin Abi Thalib adalah penulis perjanjian, apabila Nabi sedang melakukan perjanjian serta menulis perdamaian, apabila beliau saw melakukan perdamaian. Mu'aiqib bin Abi Fathimah mengurusi cincin beliau (yang menjadi stempel negara). Mu'aiqib bin Abi Fathimah menjadi penulis ghanimah (harta rampasan perang). Hudzaifah menjadi pencatat hasil pendapatan dari tanah Hijaz. Zubeir bin Awwam menjadi pencatat zakat. Mughirah bin Syu'bah menjadi pencatat hutang-hutang serta transaksi-transaksi mu'amalah. Surahbil bin Hisan menjadi penulis surat kepada raja-raja. Dalam setiap urusan beliau selalu mengangkat notulen (penulis), yang bertugas mengurus urusan meskipun yang diurusi juga beragam kepentingannya.

Demikianlah Rasulullah saw telah membangun sendiri struktur daulah Islam, kemudian beliau menyempurnakannya semasa hidup beliau. Dan beliaulah yang menjadi kepada negara. Beliau juga memiliki dua mu'awwin (pembantu), wali, amil, qadli, pasukan, dirjen departemen-departemen, serta majelis syura. Struktur ini dengan segala bentuk dan otoritasnya, adalah thariqah (tuntunan operasional) yang wajib diikuti. Dan semuanya telah dinyatakan berdasarkan riwayat yang mutawatir.

Rasulullah saw senantiasa menjalankan tugas sebagai kepala negara semenjak tiba di Madinah hingga beliau wafat, sementara Abu Bakar dan 'Umar ra adalah mu'awin beliau. Para shahabat sepeninggal beliau saw, juga telah sepakat untuk mengangkat kepala negara yang menjadi penerus Rasulullah saw dalam memimpin negara, bukan sebagai penerus kerasulan dan kenabian. Sebab, kenabian dan kerasulan telah berakhir pada beliau saja.

Kenyataan di atas telah menunjukkan, bahwa Rasulullah saw telah membangun struktur negara secara sempurna di Madinah. Selanjutnya, beliau mewariskan bentuk pemerintahan dan struktur negara yang demikian jelas dan gamblang ini kepada umat Islam.

\section{MEWUJUDKAN KEPEMIMPINAN ISLAM ADALAH SUATU KEWAJIBAN}

Prinsip yang harus diperhatikan kaum Muslim untuk memahami hakikat Khilafah di tengah gencarnya syubhat adalah: mengembalikan topik agung ini kepada pokok pembahasannya dalam Islam. Sehingga mendudukkannya sebagaimana sikap Rasulullah SAW dan para sahabat, tak terpedaya penyesatan opini yang digencarkan oleh mereka yang gelap mata, mendikte

\footnotetext{
${ }^{9} \mathrm{Ibid}, \mathrm{hlm} .25$
} 
JKPIs, Vol. 1 No. 1, 2018 | 39

Khilafah dengan kacamata kuda peradaban Barat. Padahal topik ini telah diulas para ulama rabbani pewaris para nabi, dengan pembahasan yang mapan tak mengandung kecacatan, gamblang tak mengandung kesamaran.

\subsection{Dalil Al-Qur'an}

Dalam perinciannya, kewajiban menegakkan khilafah, mencakup karakteristik agungnya, merupakan perkara yang ma'lûm disepakati salaful ummah dan ulama ahl al-sunnah wa al-jamâ'ah, bahkan disebut-sebut sebagai salah satu kefardhuan agama tersebar (min a'zhâm al-wâjibât), diuraikan dalam turâts para ulama dengan perincian dalil:

\subsubsection{Dilalah Di Balik Kewajiban Ta'at Kepada Ulil Amri (Dalil QS. Al-Nisa [4]: 59).}

Allah Swt berfirman:

$$
\text { \{09\} يَا أَيَّها الَّذِينَ آمَنُوا أَطِيعُوا اللَّهَ وَأَطِيعُوا الرَّسُولَ وَأُوِلِي الأَمْرِ مِنْكُمْ }
$$

"Wahai orang-orang yang beriman ta'atilah Allah, ta'atilah Rasul dan ulil Amri di antara kalian." (QS. Al-Nisâ' [4]: 59)

Allâh memerintahkan kita mena'ati ulil amri dalam QS. Al-Nisâ' [4]: 59. Maka berdasarkan dalâlah al-iltizam, perintah menta'ati ulil amri pun merupakan perintah mewujudkannya sehingga kewajiban tersebut terlaksana. Maka ayat tersebut pun mengandung petunjuk, wajibnya mengadakan ulil amri (Khalifah) dan sistem syar'inya (Khilafah), yang juga disebut nama (al-ism) dan dirinci konsepnya (al-musamma) dalam al-Qur'an dan hadits-hadits nabawiyyah.

Dimana Islam menetapkan bai'at syar'i sebagai metode syar'i sahnya seseorang menjadi seorang ulil amri (yakni khalifah), yang dibai'at untuk menegakkan hukum al-Qur'an dan al-Sunnah, sebagaimana ditegaskan oleh para ulama, salah satunya al-Qadhi al-'Allamah Taqiyuddin al-Nabhani, dengan berdalil dengan hadits, Rasulullah Saw bersabda:

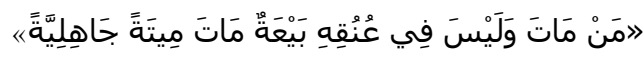

“Barangsiapa yang mati sedangkan dipundaknya tiada bai'at (kepada Khalîfah), maka ia mati seperti mati jahiliyyah." (HR. Muslim)

\subsubsection{Kedudukan Khalifah dalam Menegakkan Islam Kâffah (Dalil QS. Al-Baqarah [2]: 208 dan Lainnya)}

Allah Swt dan Rasul-Nya telah mewajibkan kaum Muslim untuk menegakkan Islam dalam kehidupan, akidah dan syari'atnya, mencakup hukum-hukum publik dalam kehidupan bermasyarakat dan bernegara, dengan segera dan tidak ditunda-tunda. Hal itu ditunjukkan oleh dasar argumentasi berikut ini:

Pertama, Islam telah turun secara sempurna, dimana kesempurnaan tersebut diikuti oleh penegasan bahwa Allah hanya meridhai Islam sebagai Din yang ditegakkan oleh manusia, berdasarkan dalil yang terang benderang dalam firman-Nya:

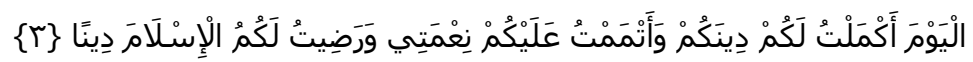

"Pada hari ini telah Kusempurnakan untuk kamu agamamu, dan telah Ku-cukupkan kepadamu nikmat-Ku, dan telah Ku-ridhai Islam itu menjadi agama bagimu.” (QS. Al-Mâ'idah [5]: 3)

Kedua, Diperjelas oleh nas-nas al-Qur'an dan al-Sunnah yang mewajibkan menegakkan Islam dalam kehidupan. Kaum Muslim, wajib menegakkan Islam keseluruhannya (kâffat[an]) dalam kehidupan sebagaimana perintah-Nya dalam banyak ayat al-Qur'an, salah satunya:

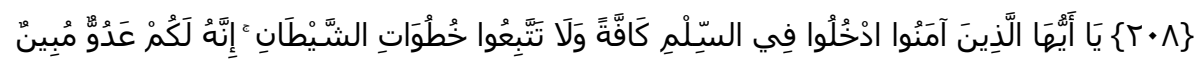

"Hai orang-orang yang beriman, masuklah kalian ke dalam Islam keseluruhan, dan janganlah mengikuti langkah-langkah syaithan. Sesungguhnya syaithan itu musuh yang nyata bagimu." (QS. Al-Baqarah [2]: 208)

Ketiga, Adanya larangan menyerupai ahli Kitab yang beriman pada sebagian Taurat dan mengkufuri sebagiannya, yang Allah ingkari, lihat QS. Al-Baqarah [2]: 85:

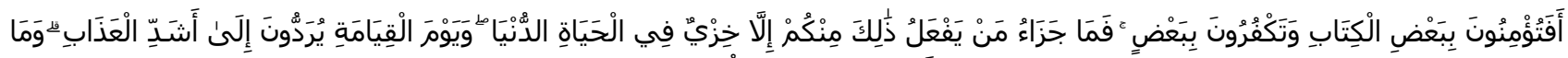

$$
\begin{aligned}
& \text { اللَّهُ بِغَافِلِ عَمَّا تَعْمَلُوَْنَ }
\end{aligned}
$$

"Apakah kamu beriman kepada sebagian al-Kitab (Taurat) dan ingkar terhadap sebagian yang lain? Tiadalah balasan bagi orang yang berbuat demikian darimu, melainkan kenistaan dalam kehidupan dunia, dan pada hari kiamat mereka dikembalikan kepada siksa yang sangat berat. Allah tidak lengah dari apa yang kamu perbuat.” (QS. Al-Baqarah [2]: 85)

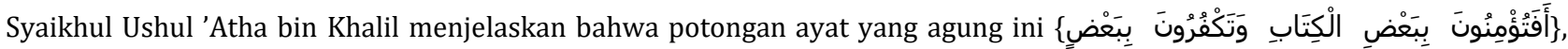
merupakan pertanyaan yang maksudnya pengingkaran (istifhâm inkâri), disertai celaan atas buruknya perbuatan mereka. Allah 
JKPIs, Vol. 1 No. 1, 2018 | 40

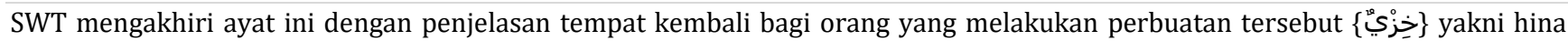
dina, rendah dan nista di dunia, ditambah dengan azab yang sangat pedih yang tiada tandingannya di akhirat kelak, serta bahwa Allah SWT tidak lengah atas perbuatan mereka yang sangat keji, bahkan mengawasi mereka, dan mengazab mereka atas apa yang

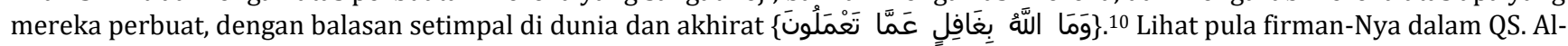
Hijr [15]: 90-91, QS. Al-Mâ'idah [5]: 49, dan lain sebagainya.

Keempat, Adanya nas-nas al-Qur'an dan al-Sunnah yang mendorong untuk bersegera beramal shalih, atau dengan kata lain menegakkan Islam dalam kehidupan.

بl-Hafizh al-Nawawi (w. 676 H) bahkan menuliskan satu bab khusus "Bersegera Terhadap Amal-Amal Kebaikan ( في "المبادرة إلى الخيرات" dalam Riyâdh al-Shâlihhîn-nya11, dimana beliau menukil firman Allah SWT:

$$
\text { كَr }
$$

"Dan bersegeralah kamu kepada ampunan dari Rabb-mu, dan kepada surga yang luasnya seluas langit dan bumi yang disediakan untuk orang-orang yang bertakwa." (QS. Âli Imrân [3]: 133)

Lihat pula QS. Al-Baqarah [2]: 148. Rasulullah SAW pun bersabda:

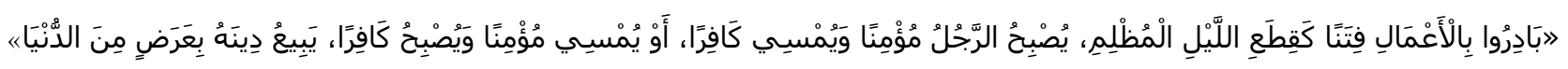

"Bersegeralah kalian beramal shalih, akan ada suatu masa ketika muncul berbagai fitnah seperti potongan malam gelap gulita, dimana seseorang beriman di waktu pagi dan kafir pada sorenya, dan beriman di waktu sore dan kafir pada paginya, ia menjual agamanya dengan harga dunia." (HR. Muslim, Ahmad) ${ }^{12}$

Imam Muslim (w. 261 H) pun meriwayatkan hadits di atas dalam bab (الحث على المبادرة بالأعمال قبل تظاهر الفتن) yakni bab mengenai dorongan untuk bersegera beramal, sebelum munculnya berbagai fitnah. Ini mengandung konsekuensi pula pada pemahaman wajibnya bersegera menegakkan Islam dalam kehidupan. Dakwah, wajib berorientasi pada poin upaya penerapan Islam keseluruhan, karena berbeda orientasi, akan melahirkan sikap yang berbeda.

Menurut Dr. Mushthafa Dib al-Bugha', di antara faidah hadits ini adalah kewajiban berpegang teguh terhadap agama, dorongan untuk menyegerakan beramal shalih sebelum tibanya berbagai penghalang dan hambatan atasnya. ${ }^{13}$ Yakni berpegang teguh pada akidah dan syari'at Islam dan bersegera beramal shalih, wa biLlâhi al-taufíq.

Kelima, Pemahaman salafuna al-shâlih, semisal teladan Khalifah Abu Bakar al-Shiddiq r.a. yang menerapkan hukum Islam secara tegas bagi mereka yang menolak menunaikan kewajiban berzakat, yakni dengan memerangi mereka yang dinilai sebagai kaum Murtad (murtaddûn), secara tegas, tidak bertahap.

Muhammad bin Yusuf al-Farabri menuturkan, disebutkan dari Abi Abdillah, dari Qabishah:

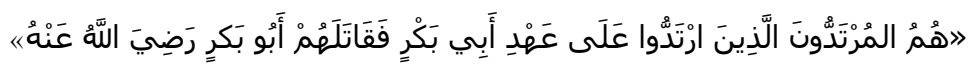

"Mereka (para penolak zakat) adalah kaum yang murtad, yang murtad pada masa Abi Bakar r.a., maka Abu Bakar memerangi mereka." (HR. Al-Bukhari) ${ }^{14}$

Sebelumnya, Umar bin al-Khaththab r.a. tidak menyetujui sikap Khalifah Abu Bakar r.a., dijawab oleh Abu Bakar r.a. dengan jawaban yang terang benderang, sehingga Umar meralat sikapnya, dan beralih menyetujui kebijakan benar Khalifah Abu Bakar r.a. dengan menyatakan:

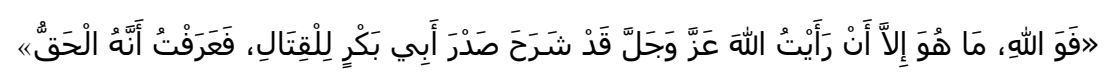

"Demi Allah, tidaklah ada pada dirinya, kecuali aku menyaksikan Allah Azza wa Jalla sungguh telah melapangkan hati Abu Bakar untuk memerangi (para penolak zakat), sehingga aku mengetahui bahwa ia benar." (HR. Al-Bukhari, Muslim \& Ahmad) ${ }^{15}$

Sehingga sikap Abu Bakar ini disepakati oleh seluruh sahabat, dan dinilai sebagai ijma' (konsensus) mereka. ${ }^{16}$ Sehingga penegakkan Islam keseluruhannya dalam kehidupan sesuatu yang wajib disegerakan, tak bisa ditawar-tawar lagi, sehingga setiap gerakan yang memproklamirkan identitasnya sebagai gerakan dakwah Islam, sudah seharusnya menjadikan penegakkan Islam

\footnotetext{
10 'Atha bin Khalil Abu al-Rasythah, Al-Taysîr fì Ushûl al-Tafsîr: Sûrat al-Baqarah, hlm. 107-108.

${ }^{11}$ Abu Zakariya Muhyiddin Yahya bin Syarf al-Nawawi, Riyâdh al-Shalihîn, Beirut: Mu'assasat al-Risâlah, cet. III, 1419 H/1998, hlm. 63.

${ }^{12}$ HR. Muslim dalam Shahîh $\underline{h}$-nya (no. 118); Ahmad dalam Musnad-nya (no. 9267), Syaikh Syu'aib al-Arna'uth mengomentari: “Sanadnya shahih sesuai syarat Imam Muslim, para perawinya perawi tsiqah perawi syaikhain (al-Bukhari dan Muslim) kecuali Ziyad bin Riyah, maka ia perawi Imam Musim saja."

13 Ibid.

${ }^{14}$ HR. Al-Bukhari dalam Shậํh-nya (no. 3447).

${ }^{15}$ HR. Al-Bukhari dalam Sha $\underline{h} \underline{\hat{i}} \underline{h}$-nya (no. 1388); Muslim dalam Shahîh $\underline{h}$-nya (no. 20); Ahmad dalam Musnad-nya (no. 117), Syaikh Syu'aib al-Arna'uth mengomentari: "Sanadnya shahih sesuai syarat syaikhain, kecuali 'Isham bin Khalid karena ia perawi Imam al-Bukhari saja." ; Abu Dawud dalam Sunan-nya (no. 1558).

${ }^{16}$ Dr. 'Athiyyah 'Adlan, “Tahkîm al-Syarî’ah, Al-Tadarruj Lâ al-Taswîf”, Majallat al-Bayân, Tahun ke-27, no. 303, September 2015, hlm. 10. .
} 
JKPIs, Vol. 1 No. 1, 2018 | 41

kâffah dalam kehidupan sebagai salah satu prioritas utamanya. Dakwah kepada akidah Islam dan hukum-hukum Islam yang menasakh syari'at para nabi terdahulu, ${ }^{17}$ bukan kepada akidah dan hukum-hukum selainnya.

Perincian argumentasi syar'i terkait persoalan ini, dari nas-nas al-Qur'an dan al-Sunnah, bisa dirujuk lebih jauh dalam kitab Min Muqawwimât al-Nafsiyyah al-Islâmiyyah. ${ }^{18}$

Poin penting lainnya, dalam perinciannya para ulama menjelaskan bahwa penegakkan Islam dalam kehidupan, takkan sempurna terealisasi kecuali dengan adanya Khalifah dan tegaknya sistem Khilafah, maka menegakkan keduanya fardhu, sesuai kaidah syar'iyyah yang lalu dinukil oleh para ulama:

$$
\text { مَا لاَ يَتِمُّ الْوَابِبُ إِلآَ بِهِ فَهُوَ وَاجِبٌ }
$$

"Hal-hal dimana suatu kewajiban tidak sempurna kecuali dengannya, maka hukumnya pun wajib."19

Para ulama pun menjadikan kaidah ini: sebagai penguat hujjah kefardhuan adanya Khalifah dan tegaknya sistem Khilafah, sebagaimana diutarakan oleh Imam al-Naisaburi (w. $850 \mathrm{H}$ ):

"Umat ini (ulama) bersepakat bahwa yang diseru dari firman-Nya: "Jilidlah" adalah Imam hingga mereka pun berhujjah dengannya atas kewajiban mengangkat Imam (Khalifah), karena sesungguhnya hal dimana kewajiban takkan sempurna kecuali dengannya maka hal tersebut menjadi wajib adanya." 20

Al-Qadhi Abu Ya'la al-Farra (w. 458 H) ketika menjelaskan kaidah ini menuturkan, bahwa jika Allah sudah memerintahkan hamba-Nya untuk menunaikan suatu perbuatan dan Allah mewajibkannya, di sisi lain apa yang diperintahkan tersebut takkan tercapai sempurna kecuali dengan hal lainnya; maka hal tersebut menjadi wajib adanya. ${ }^{21}$ Hal ini sebagaimana diungkapkan Imam al-Qarafi (w. $684 \mathrm{H}$ ) yang berkata:

$$
\text { وُجحُوْبُ الوَسَائِل تِبع لِوُجُوْبِ المَقَاصِد }
$$

“Wajibnya sarana-sarana mengikuti wajibnya tujuan-tujuan."22

\subsection{Dalil Al-Sunnah}

\subsubsection{Dalil Hadits Pujian Rasulullah Saw Kepada Sosok Imam/Khalifah}

Banyak dalil-dalil al-Sunnah yang mendasari wajibnya khilafah: hadits dari Abu Hurairah r.a., bahwa Nabi SAW bersabda:

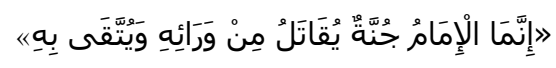

"Sesungguhnya al-imam (khalifah) itu perisai, dimana (orang-orang) akan berperang mendukungnya dan berlindung (dari musuh) dengan (kekuasaan) nya." (HR. Muttafaqun 'Alaih)

Hadits ini mengandung pujian yang sangat kuat terhadap sosok Khalifah, karena maksud dari al-Imâm dalam hadits ini adalah Khalîfah. Al-Mulla Ali al-Qari (w. 1041 H) secara gamblang menyatakan:

$$
\text { فَإِنَمَا الِْإمَامُ أَي الْخَلِيفَةُ أَوْ أَمِيرُةُ }
$$

"Makna kalimat (إنما الإمام) yakni al-Khalifah atau Amirnya."23

Imam al-Munawi al-Qahiri (w. $1031 \mathrm{H}$ ) pun menegaskan bahwa al-Imam dalam hadits ini yakni al-Imam al-A'zham²4, istilah yang sama diungkapkan oleh ulama mujtahid penulis kitab Subul al-Salâm, Imam al-Shan'ani (w. 1182 H) ${ }^{25}$, dimana para ulama ketika menyebut al-Imâm al-A'zham berkonotasi Imâm al-Muslimîn, dan Imâm al-Muslimîn adalah al-Khalifah, sebagaimana disebutkan Prof. Dr. Muhammad Rawwas Qal'ah Ji (w. 1435 H) dalam Mu'jam Lughat al-Fuqahâ', dan sistem pemerintahan yang dipimpin oleh al-Khalifah adalah al-Khilâfah yang disebut para ulama sebagai al-Imâmah al-Kubrâ' (kepemimpinan agung). ${ }^{26}$

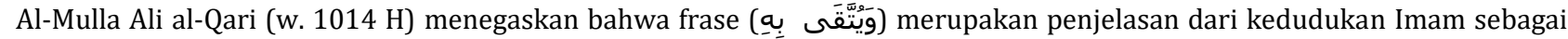
junnah (perisai), bahwa karakter junnah (perisai) dalam hadits ini lebih tepat berlaku dalam seluruh keadaan; karena seorang

\footnotetext{
17 'Atha bin Khalil Abu al-Rasythah, Al-Taysîr fì Ushûl Al-Tafsîr: Sûrat al-Baqarah, hlm. 163.

${ }^{18}$ Hizbut Tahrir, Min Muqawwimât al-Nafsiyyah al-Islâmiyyah, Beirut: Dâr al-Ummah, cet. I, 1425 H/2004, hlm. 11-16.

${ }^{19}$ Tajuddin 'Abdul Wahhab al-Subki, Al-Asybâh wa al-Nazhâ'ir, Dâr al-Kutub al-Ilmiyyah, II/88

${ }^{20}$ Nizhamuddin al-Naisaburi, Gharâ'ib al-Qur'ân wa Raghâ'ib al-Furqân, Dâr al-Kutub al-'Ilmiyyah, V/148

${ }^{21}$ Ibid.

${ }^{22}$ Abu al-'Abbas Syihabuddin Ahmad al-Qarafi, Al-Furûq: Anwâr al-Burûq fỉ Anwâ’i al-Furûq, Beirut: Dâr al-Kutub al-'Ilmiyyah, 1418 H/1998, juz I, hlm. 302.

23 'Ali bin Sulthan Muhammad Abu al-Hasan al-Mala al-Qari, Mirqât al-Mafâtîh Syarh Misykât al-Mashâbîh, juz VI, hlm. 2391.

${ }^{24}$ Abdurra'uf bin Tajul Arifin bin Ali al-Manawi, Faydh al-Qadîr Syarh al-Jâmi' al-Shaghîr, Mesir: Al-Maktabah al-Tijâriyyah al-Kubrâ', cet. I, 1356 H, juz II, hlm. 559.

${ }^{25}$ Muhammad bin Isma'il al-Kahlani al-Shan’ani, Al-Tanwiir Syarh al-Jâmi’ al-Shaghiir, Ed: Dr. Muhammad Ishaq, Riyadh: Maktabat Dâr al-Salâm, cet. I, 1432 H/2011, juz IV, hlm. 166.

${ }^{26}$ Prof. Dr. Muhammad Rawwas Qal'ah Ji dkk, Mu'jam Lughat al-Fuqahâ', Beirut: Dâr al-Nafâ'is, cet. II, 1408 H/1988, hlm. 88.
} 
JKPIs, Vol. 1 No. 1, 2018 | 42 penguasa menjadi pelindung bagi kaum Muslim dalam memenuhi kebutuhan-kebutuhannya secara berkelanjutan. ${ }^{27}$ al-Hafizh Ibn al-Atsir (w. $606 \mathrm{H}$ ) menjelaskan bahwa junnah dalam hadits ini, berkonotasi pula sebagai pelindung dari kezhaliman, penangkal dari keburukan. ${ }^{28}$ Sebagaimana dijelaskan oleh para ulama lainnya, di antaranya al-Hafizh al-Nawawi (w. $676 \mathrm{H}$ ) yang berkata:

Sabda Rasulullah SAW: (الإمام جنة) yakni seperti al-sitr (pelindung), karena Imam (Khalifah) mencegah musuh dari perbuatan mencelakai kaum Muslim, dan mencegah sesama manusia (melakukan kezhaliman-pen.), memelihara kemurnian ajaran Islam, rakyat berlindung kepadanya dan mereka tunduk kepada kekuasaannya. ${ }^{29}$

Penjelasan hampir senada, disebutkan Imam al-Thibi (w. 743 H) dalam syarh-nya atas Misykât al-Mashâbîh ${ }^{30}$, Imam Syamsuddin al-Kirmani (w. 786 H) dalam syarh-nya atas Shahîh al-Bukhârî̉ ${ }^{31}$, Imam Shadruddin al-Munawi (w. 803 H) ${ }^{32}$, Imam Ibn al-Mulqan (w. 804 H) dalam syarh-nya atas al-Jâmi' al-Shaghîr 33, al-Hafizh al-Suyuthi (w. 911 H) dalam syarh-nya atas Shahîh Muslim $^{34}$, dan al-Hafizh Ibnu Hajar al-'Asqalani (w. 852 H) dalam kitab syarh-nya atas Shahîh al-Bukhârî yang menjelaskan sifat alImam sebagai junnah yakni pelindung dari kejahatan musuh dan perbuatan saling menzhalimi. ${ }^{35}$

Jika adanya "hal yang dipuji" tersebut menjadi sebab tegaknya hukum Islam, sebaliknya jika ia tiada menyebabkan hukum Islam terbengkalai, maka pujian tersebut merupakan qarînah jazîmah (indikasi tegas) bahwa "hal yang dipuji" tersebut hukumnya wajib, yakni diangkatnya Khalifah dan tegaknya sistem Khilafah.

Terlebih jika ketiadaan Khalifah yang menegakkan Islam dalam kehidupan, bisa melahirkan kerusakan demi kerusakan, fitnah bagi masyarakat. Imam Ahmad bin Hanbal (w. $241 \mathrm{H}$ ) pun tak ragu untuk berkata:

$$
\text { والفتنة: إذا لم يكن إمام يقوم بأمر الناس }
$$

"Fitnah terjadi jika tidak ada Imam (Khalifah) yang berdiri untuk mengatur manusia (dengan hukum-hukum Islam-pen.)."36

\subsubsection{Dalil Hadits Wajib Tegaknya Bai'at Dipundak Kaum Muslim Kepada Khalifah}

Dalil lainnya, Rasulullah SAW bersabda:

$$
\text { 》مَنْ مَاتَ وَلَيْسَ فِي عُنُقِهِ بَيْعَةٌ مَاتَ مِيتَةً جَاهِلِيَّةً }
$$

“Barangsiapa yang mati sedangkan dipundaknya tiada bai'at (kepada Khalîfah), maka ia mati seperti mati jahiliyyah.” (HR. Muslim)

Bai'at secara terminologis adalah hak umat dalam melaksanakan akad penyerahan kekhilafahan. Para ulama menegaskan bahwa bai'at merupakan metode syar'i mengangkat Khalîfah. ${ }^{37}$ Nabi SAW telah mewajibkan adanya bai' at di pundak setiap muslim, dengan qarînah jâzimah adanya ancaman tasybîh: mati seperti mati jahiliyyah, menurut al-Hafizh Ibn Hajar al-'Asqalani (w. 852 H) yakni mati dalam keadaan bermaksiat. 38

Para ulama, salah satunya al-Qadhi Taqiyuddin al-Nabhani menegaskan bahwa hadits ini mewajibkan adanya bai'at di atas pundak setiap Muslim, dan bai'at tidak diberikan kecuali kepada Khalifah, maka ini menjadi dalil wajibnya mengadakan Khalifah, menegakkan sistem Khilafah dengan batas tempo hanya tiga hari.

Imam Ibn Hubairah (w. $560 \mathrm{H}$ ) pun menjelaskan hadits ini menegaskan:

Yakni jika tiada Imam/Khalifah baginya, dan ini menunjukkan bahwa tidak boleh terjadi kekosongan yang meliputi kaum Muslim, lebih dari tiga hari sebagai tempo syura' (dari ketiadaan khilafah), kecuali di pundak mereka terdapat bai'at terhadap seorang Khalifah tempat kembali mereka. ${ }^{39}$

\subsubsection{Dalil Hadits Tidak Halal Adanya Jama'ah Tanpa Ada Pemimpin}

Setiap jama'ah harus mempunyai seorang pemimpin (amir) yang wajib dita'ati. Hal itu sesuai dengan perintah syara' yang mewajibkan setiap jama'ah yang terdiri dari tiga orang atau lebih untuk memiliki seorang amir. Rasulullah SAW bersabda:

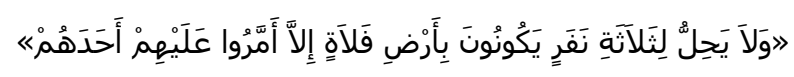

\footnotetext{
${ }^{27}$ Al-Mulla' Ali al-Qari, Mirqât al-Mafâtîh Syarh Misykât al-Mashâbîh $\underline{h}$ juz VI, hlm. 2391.

${ }^{28}$ Majduddin Abu al-Sa'adat al-Mubarak Ibn al-Atsir, Jâmi' al-Ushûl fî̀ Ahâdîts al-Rasûl, Maktabat Dâr al-Bayân, cet. I, 1390 H, juz IV, hlm. 63.

${ }^{29}$ Al-Hafizh al-Nawawi, Al-Minhâj Syarh Shahîh Muslim, juz. XII, hlm. 230.

${ }^{30}$ Syarfuddin al-Husain al-Thibi, Al-Kâsyif 'an Haqâ' 'iq al-Sunan, juz VIII, hlm. 2557.

31 Muhammad bin Yusuf Syamsuddin al-Kirmani, Al-Kawâkib al-Durârî fì Syarh Shahîh al-Bukhârî, Beirut: Dâr Ihyâ' al-Turâts al-'Arabi, cet. I, 1401 H/1981, juz XII, hlm. 197.

${ }^{32}$ Al-Munawi al-Qahiri al-Syafi'i, Kasyf al-Manâhij wa al-Tanâqîh fî Takhrîj Ahâdîts al-Mashâbîh, Beirut: al-Dâr al-’Arabiyyah li al-Mausû'ât, cet. I, 1425 H, juz III, hlm. 265.

${ }^{33}$ Ibn al-Mulqan, Al-Taudhîh li Syarh al-Jâmi' al-Shaghîr, Damaskus: Dâr al-Nawâdir, cet. I, 1429 H/2008, juz XVIII, hlm. 67.

${ }^{34}$ Al-Hafizh Jalaluddin al-Suyuthi, Al-Dîbâj 'alâ Shahîh $\underline{h}$ Muslim bin al-Hijâz, KSA: Dâr Ibn 'Affân, cet. I, 1416 H, juz IV, hlm. 454.

${ }^{35}$ Ibn Hajar al-'Asqalani, Fath al-Bâri Syarh Shahîh $\underline{h}$ al-Bukhâri, juz VI, hlm. 116.

${ }^{36}$ Ahmad bin Muhammad al-Khallal, Al-Sunnah, Riyadh: Dâr al-Râyah, cet. I, 1410 H, juz III, hlm. 81. Dalam catatan kaki kitab ini disebutkan bahwa atsar ini sanadnya shahih dan madzhab ahlus sunnah memandang wajibnya mengangkat Imam (khalifah) yang memelihara kemaslahatan masyarakat.

${ }^{37} \mathrm{Hal}$ ini disimpulkan dari ulasan para ulama terkait bai'at untuk khalifah, misalnya dalam kitab al-Ahkâm al-Sulthaniyyah karya Imam al-Mawardi.

${ }^{38}$ Ahmad bin Ali al-Asqalani, Fath al-Bâri, juz XIII, hlm. 7.

${ }^{39}$ Yahya bin Hubairah al-Syaibani, Al-Ifshâh 'An Ma'âni al-Shihâh, Dâr al-Wathan, IV/262
} 
"Tidak halal bagi tiga orang yang berjalan di muka Bumi, kecuali mengangkat salah seorang dari mereka sebagai pemimpinnya." (HR. Ahmad, al-Thabrani) ${ }^{40}$

Hadits ini, banyak dinukil para ulama sebagai salah satu dalil wajibnya adanya al-Imâm atau al-Khalîfah, dan qadhi, semisal

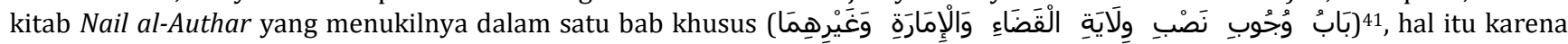
keumuman khabar dan lafal dalam hadits ini.42

Sehingga tidak mengherankan jika hadits ini pun dinukil para ulama sebagai dalil wajibnya mengangkat Khalifah, sebagaimana ia pun dinukil oleh al-'Allamah Abdul Qadim Zallum, untuk menegaskan kewajiban adanya pemimpin dalam dakwah.43 Kalimat lâ yahillu, menunjukkan larangan keras (qarînah jâzimah), menunjukkan keharaman atas ketiadaan amîr (pemimpin). Jika dalam persoalan safar saja wajib ditunjuk salah seorang pemimpin (amîr al-safar), maka perkara kehidupan umat yang lebih kompleks persoalannya, lebih utama (awlâ) membutuhkan adanya kepemimpinan.

Prof. Dr. Muhammad Ahmad Mufti menegaskan dalam subjudul Pentingnya Kedudukan Kekuasaan Politis dalam Islam ( ضرورة (السلطة السياسية في الإسلام:

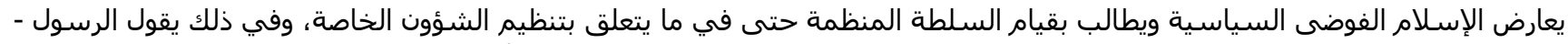

$$
\begin{aligned}
& \text { صلى الله عليه وسلم-: ((إذا خرج ثلاثة في سفي سفر فلي ما ينعليؤمروا أحدهم)) }
\end{aligned}
$$

Islam menolak segala kekacaun politis dan menuntut kekuasaan yang teratur hingga pada pengaturan berbagai urusan khusus. Dalam hal ini Rasulullah SAW bersabda: "Jika tiga orang bepergian maka angkatlah salah satunya menjadi pemimpin. 44

Lalu ia pun menegaskan bahwa para ahli fikih menggali hukum tentang kewajiban adanya kepemimpinan politik dan masyarakat yang politis yang teratur. Syaikh Ibn Taimiyyah menjelaskan bahwa jika Rasulullah Saw telah mewajibkan adanya kepemimpinan ini terhadap lingkup kecil, maka hal ini menjadi dalil yang sangat jelas terhadap kewajiban adanya kepemimpinan politis bagi lingkup masyarakat yang lebih luas yakni umat ini.

\subsection{Dalil Ijma' Sahabat}

Jika konsep khilafah dipertentangkan dengan konsep lain yang mengatasnamakan kesepakatan, maka harus kembali kepada prinsip bahwa ijma' sahabat, menurut ahl al-'ilm, menjadi hujjah syar'i berdasarkan dalil QS. Al-Taubah [9]: 100, diunggulkan atas kesepakatan manusia manapun. Dimana sahabat berijma' atas wajibnya menegakkan khilafah, mengangkat khalifah. Al-Qadhi Abu Ya'la al-Farra (w. 458 H) ketika mengomentari peristiwa bersejarah diskusi alot antara tokoh-tokoh Kaum Anshar dan Kaum Muhajirin menegaskan: "Jika seandainya al-Imamah (Khilafah) itu tidak wajib, maka takkan berlangsung diskusi alot tersebut dan dialog tentangnya." 45

Sebelumnya, al-Farra menegaskan bahwa Khilafah hukumnya wajib berdasarkan dalil al-sam'u (yakni dalil-dalil naqli).46 Penjelasan senada ditegaskan oleh al-Hafizh al-Qurthubi (w. $671 \mathrm{H}$ ) dalam kitab tafsirnya. ${ }^{47}$ Di sisi lain, para sahabat pun lebih mendahulukan pengangkatan Khalifah daripada pemakaman jenazah Rasulullah SAW, sebagaimana ditegaskan oleh Imam alKhaththabi (w. 388 H). Setelah menjelaskan ijma' sahabat ini, al-Khaththabi (w. 388 H) lalu menegaskan:

$$
\text { وذلك من أدل الدليل على وجوب الخلافة وأنه لا بد للناس من إمام يقوم بأمر الناس ويمضي فيهم أحكام الله ويردعهم عن الشـر ويمنعهم }
$$

Dan dalil tersebut (ijma' sahabat) merupakan sejelas-jelasnya dalil atas wajibnya menegakkan al-Khilafah dan bahwa harus ada seorang Imam (Khalifah) bagi masyarakat yang berdiri memerintah dan mengatur mereka dengan hukum-hukum Allah, menjauhkan mereka dari keburukan, menghalangi mereka saling menzhalimi dan merusak. ${ }^{48}$

Maka tak mengherankan jika para ulama pun menegaskan kesepakatan mereka atas wajibnya menegakkan Khilafah. Imam Ibn Hazm (w. 456 H) mendokumentasikan: "Mereka (para ulama) sepakat bahwa imamah itu fardhu dan adanya Imam itu merupakan suatu keharusan." 49

\section{Pendapat Ulama Mu'tabar Tentang Wajibnya Khilafah}

Syeikh Al-Islam Al Imam Al Hafidz Abu Zakaria An Nawawi berkata:

\footnotetext{
${ }^{40}$ HR. Ahmad dalam Musnad-nya (no. 6647), Syaikh Syu'aib al-Arna'uth mengomentari: “Shahih li ghairihi kecuali hadits al-imârat maka derajatnya hasan."; HR. Al-Thabrani dalam al-Mu'jam al-Kabîr (no. 14723).

${ }^{41}$ Muhammad bin Ali al-Syaukani, Nail al-Authâr, Mesir: Dâr al-Hadîts, cet. I, 1413 H/1993, juz VIII, hlm. 294.

${ }^{42} \mathrm{Hal}$ ini sebagaimana mafhum yang dibangun oleh Imam Ibn al-Arabi ketika memahami keumuman dalil larangan berbisik-bisik di antara dua orang tanpa

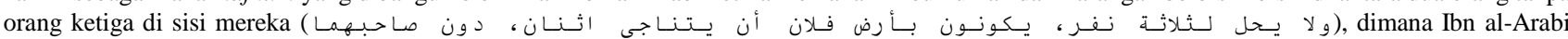
menjelaskan bahwa hadits ini, khabarnya umum, makna dan lafalnya, dan alasannya karena bisa menimbulkan kesedihan (pada orang yang tidak diajak bicara-pen.), dimana hal tersebut bisa terjadi baik dalam safar maupun ketika diam di suatu tempat, maka larangan tersebut harus mencakup kedua kondisi

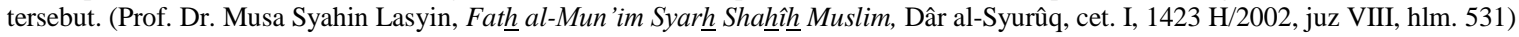

${ }^{43}$ Abdul Qadim Zallum, Afkâr Siyâsiyyah, hlm. 56.

${ }^{44}$ Prof. Dr. Muhammad Ahmad Mufti, Arkânun wa Dhamânât: Al-Hukm Al-Islâmi, Beirut: Mu'assasat al-Risâlah.

${ }^{45}$ Abu Ya'la al-Farra, Al-Ahkâm al-Sulthâniyyah, Dâr al-Kutub al-'Ilmiyyah, juz I, hlm. 19.

46 Ibid

${ }^{47}$ Abu Abdullah Al-Qurthubi, Al-Jâmi' li Ahkâm al-Qur'ân, Dâr 'Âlam al-Kutub, I/264

${ }^{48}$ Abu Sulaiman al-Khathabi, Ma'âlim al-Sunan, Al-Mathba'ah al-'Ilmiyyah, juz III, hlm. 6

${ }^{49}$ Ibn Hazm Al-Andalusi, Marâtib al-Ijmâ', Dâr al-Kutub al-'Ilmiyyah, juz I, hlm. 124
} 
JKPIs, Vol. 1 No. 1, 2018 | 44

الفصل الثاني في وجوب الإمامة وبيان طرقها لا بد للأمة من إمام يقيم الدين وينصر السنة وينتصف للمظلومين ويستوفي الحقوق ويضعها

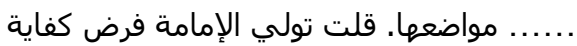

“...Pasal kedua tentang wajibnya imamah serta penjelasan mengenai metode (jalan untuk mewujudkannya). Adalah suatu keharusan bagi umat adanya seorang imam yang bertugas menegakkan agama, menolong sunnah, membela orang yang didzalimi, menunaikan hak, dan menempatkan hak pada tempatnya. Saya nyatakan bahwa mengurusi urusan imamah itu adalah fardhu kifayah". [Imam Al Hafidz Abu Zakaria Yahya bin Syaraf bin Marwa An Nawawi, Raudhatuth Thalibin wa Umdatul Muftin, juz III hal 433].

Penulis kitab Tuhfatul Muhtaj fii Syarhil Minhaj menyatakan:

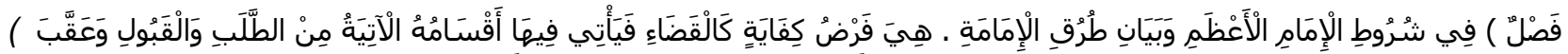

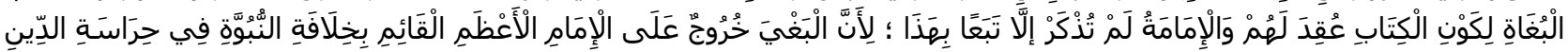

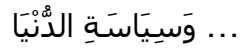

“...(Pasal) tentang syarat-syarat imam agung (khalifah) serta penjelasan metode-metode pengangkatan imamah. Mewujudkan imamah itu adalah fardhu kifayah sebagaimana peradilan”. [Tuhfatul Muhtaj fii Syarhil Minhaj, juz 34 hal 159]

Syeikh Al-Islam Imam Al-hafidz Abu Yahya Zakaria Al-anshari dalam kitab Fathul Wahab bi Syarhi Minhajith Thullab berkata:

فصل) في شـروط الامام الاعظم، وفي بيان طرق انعقاد الامامة، وهي فرض كفاية كالقضاء (شـرط الامام كونه أهلا للقضاء) بأن يكون )

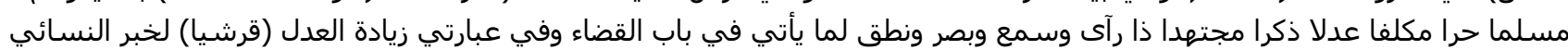

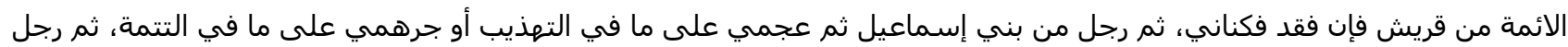

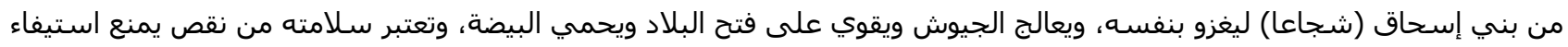

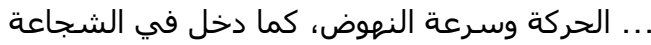

[Syaikhul Islam Imam Al Hafidz Abu Yahya Zakaria Al-Anshari, Fathul Wahab bi Syarhi Minhajith Thullab, juz 2, hal 268].

“...(Pasal) tentang syarat-syarat imam yang agung serta penjelasan metode in'iqad (pengangkatan) imamah. Mewujudkan imamah itu adalah fardhu kifayah sebagaimana peradilan (salah satu syarat menjadi imam adalah ahli dalam peradilan). Maka hendaknya imam yang agung tersebut adalah muslim, merdeka, mukallaf, adil, laki-laki, mujtahid, memiliki visi, bisa mendengar, melihat dan bisa bicara; semua ini berdasarkan syarat-syarat pada bab peradilan dan pada ungkapan saya dengan penambahan adil adalah (dari kabilah Quraisy) berdasarkan hadits yang diriwayatkan oleh An Nasa'I: "bahwa para Imam itu dari golongan Quraisy". Apabila tidak ada golongan Quraisy maka dari Kinanah, kemudian pria dari keturunan Ismail lalu orang asing (selain orang Arab) berdasarkan apa yang ada pada (kitab) At-tahdzib atau Jurhumi berdasarkan apa yang terdapat dalam (kitab) Attatimmah. Kemudian pria dari keturunan Ishaq. Selanjutnya (pemberani) agar (berani) berperang dengan diri sendiri, mengatur pasukan serta memperkuat (pasukan) untuk menaklukkan negeri serta melindungi kemurnian (Islam). Juga termasuk (sebagian dari syarat imamah) adalah bebas dari kekurangan yang akan menghalangi kesempurnaan serta cekatannya gerakan sebagaimana hal tersebut merupakan bagian dari keberanian ..." [Syaikhul Islam Imam Al-hafidz Abu Yahya Zakaria Al-anshri, Fathul Wahab bi Syarhi Minhajith Thullab, juz 2 hal 268].

Imam Fakhruddin Al Razi, penulis kitab Manaqib Asy Syafi'i, tatkala menjelaskan surat Al Maidah :38, beliau menegaskan:

احتج المتكلمون بهذه الآية في أنه يجب على الأمة أن ينصبوا لأنفسهم إماماً معيناً والدليل عليه أنه تعالى أوجب بهذه الآية إلى إقامة الحد ...

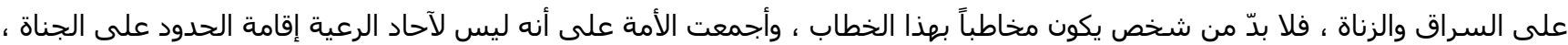

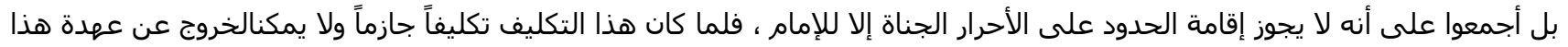

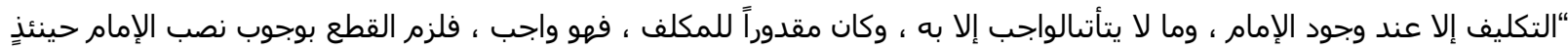

“... para Mutakallimin berhujjah dengan ayat ini bahwa wajib atas umat untuk mengangkat seorang imam tertentu untuk mereka. Dalilnya adalah bahwa Dia Ta'ala mewajibkan di dalam ayat ini untuk menegakkan had atas pencuri dan pelaku zina. Maka, adalah keharusan adanya seseorang yang melaksanakan seruan tersebut. Sungguh umat telah sepakat bahwa tidak seorangpun dari rakyat yang boleh menegakkan had atas pelaku criminal tersebut. Bahkan mereka telah sepakat bahwa tidak boleh (haram) menegakkan had atas pelaku kriminal yang merdeka kecuali oleh imam. Karena itu ketika taklif tersebut sifatnya pasti (jazim) dan ketika tidak mungkin keluar dari ikatan taklif ini kecuali ketika adanya imam, dan ketika kewajiban itu tidak tertunaikan kecuali dengan adanya imam, dan ketika kewajiban itu masih dalam batas kemampuan mukallaf, maka (adanya) imam adalah wajib. Oleh karena itu, seketika itu juga, kewajiban mengangkat seorang Imam adalah sesuatu yang bersifat qath'i..." [ Imam Fakhruddin Ar-razi, Mafatihul Ghaib fii At-tafsir, juz 6 hal. 57 dan 233].

Imam Abul Qasim An Naisaburi Asy Syafi'i berkata:

أجمعت الأمة على أن المخاطب بقوله \} فاجلدوا \{ هو الإمام حتى احتجوا به على وجوب نصب الإمام فإن ما لا يتم الواجب إلا به فهو ... واجب. 
JKPIs, Vol. 1 No. 1, 2018 | 45

“...umat telah sepakat bahwa yang menjadi obyek khitab pada firmanNya: ("maka jilidlah") adalah imam; sehingga mereka berhujjah dengan ayat ini atas wajibnya mengangkat seorang imam. Sebab, apabila suatu kewajiban itu tidak sempurna tanpa adanya sesuatu maka sesuatu tersebut menjadi wajib pula". [Imam Abul Qasim Al Hasan bin Muhammad bin Habib bin Ayyub Asy Syafi'iy An Naisaburi, Tafsir An Naisaburi, juz 5 hal 465 ].

Al-'Allamah Asy Syeikh Abdul Hamid Asy Syarwani menyatakan:

...قوله: (هي فرض كفاية) إذ لا بد للامة من إمام يقيم الدين وينصر السنة وينصف المظلوم من الظالم ويستوفي الحقوق ويضعها موضعها

“...perkataannya: (mewujudkan imamah itu adalah fardhu kifayah) karena adalah merupakan keharusan bagi umat adanya imam yang bertugas menegakkan agama, menolong sunnah, serta memberikan hak orang yang didzalimi dari orang yang dzalim serta menunaikan hak-hak dan menempatkan hak-hak tersebut pada tempatnya..." [Asy Syeikh Abdul Hamid Asy Syarwani, Hawasyi Asy Syarwani, juz 9, hal 74].

Al ‘Allamah Asy Syeikh Sulaiman bin Umar bin Muhammad Al Bajairami berkata:

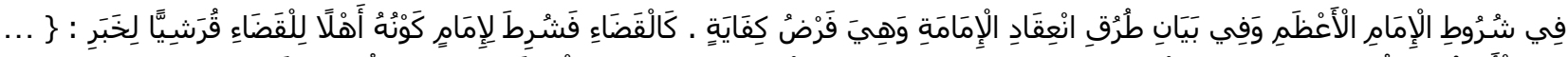

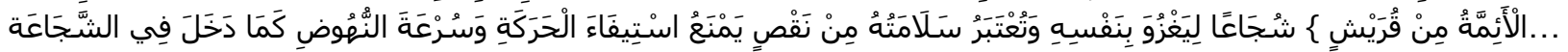

“...tentang syarat-syarat imam yang agung serta penjelasan metode-metode sahnya in'iqad imamah. Mewujudkan imamah tersebut adalah fardhu kifayah sebagaimana peradilan. Disyaratkan untuk seorang imam, hendaknya ia memiliki keahlian dalam peradilan; dan dari suku Quraisy, berdasarkan hadits, "Para imam itu dari Quraisy"; berani, agar berani berperang secara langsung; tidak memiliki cacat kekurangan yang menghalangi kesempurnaan dan kegesitan gerakan nya sebagaimana masuknya keberanian sebagai salah satu syarat imamah..." [ Syeikh Sulaiman bin Umar bin Muhammad Al Bajairami, Hasyiyah Al Bajairami 'ala Al Khathib, juz 12 hal 393].

Dalam kitab Hasyiyyah Al-bajairimi alal Minhaj dinyatakan:

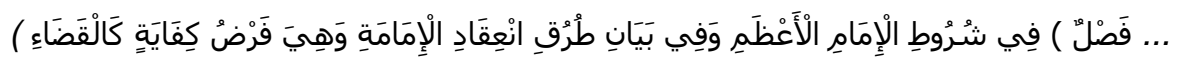

“...(Pasal) tentang syarat-syarat imam agung dan penjelasan metode-metode in'iqad imamah. Dan (adanya) imamah itu adalah fardhu kifayah sebagaimana peradilan..." [Hasyiyyah Al Bajayrimi ala Al Minhaj, juz 15 hal 66.

Imam Al-hafidz Abu Muhammad Ali bin Hazm Al Andalusi Adz Dzahiri mendokumentasikan ijma' ulama' mengenai kefardluan menegakkan imamah:

$$
\begin{aligned}
& \text { واتفقوا أن الإمامة فرض وإنه لا بد من إمام حاشا النجدات وأراهم قد حادوا الإجماع وقد تقدمهم واتفقوا أنه لا يجوز أن يكون على .... }
\end{aligned}
$$

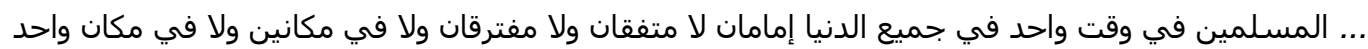

“...Meraka (para ulama') sepakat bahwa imamah itu fardhu dan adanya imam itu merupakan suatu keharusan, kecuali An Najdat. Pendapat mereka sungguh telah menyalahi ijma' dan telah lewat pembahasan (tentang) mereka. Mereka (para ulama') sepakat bahwa tidak boleh pada satu waktu di seluruh dunia adanya dua imam bagi kaum Muslimin baik mereka sepakat atau tidak, baik mereka berada di satu tempat atau di dua tempat..." [Imam Al Hafidz Abu Muhammad, Ali bin Hazm Al Andalusi Adz Dzahiri, Maratibul Ijma', juz 1 hal 124].

Imam 'Alauddin Al Kasani Al Hanafi berkata:

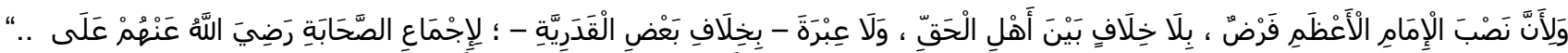

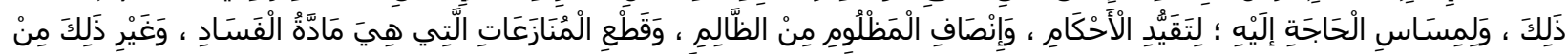

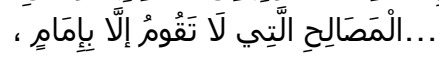

“...dan karena sesungguhnya mengangkat imam agung itu adalah fardhu. Tidak ada perbedaan pendapat diantara ahlul haq mengenai masalah ini. Khilafah sebagian kelompok Qadariyyah sama sekali tidak perlu diperhatikan, berdasarkan ijma' shahabat ra atas perkara itu, serta kebutuhan terhadap imam yang agung tersebut; serta demi keterikatan dengan hukum; dan untuk menyelamatkan orang yang didzalimi dari orang yang dzalim; memutuskan perselisihan yang menjadi sumber kerusakan, dan kemaslahatan-kemaslahatan lain yang tidak akan terwujud kecuali dengan adanya imam..." [Imam 'Alauddin Al-Kassani Al Hanafi, Bada'iush Shanai' fii Tartibis Syarai', juz 14 hal. 406

Imam Al Hafidz Abul Fida' Ismail ibn Katsir ketika menjelaskan firman Allah surah Al Baqarah ayat 30 beliau berkata: 
JKPIs, Vol. 1 No. 1, 2018 | 46

وقد استدل القرطبي وغيره بهذه الآية على وجوب نصب الخليفة ليفصل بين الناس فيما يختلفون فيه، ويقطع تنازعهمر، وينتصر ...

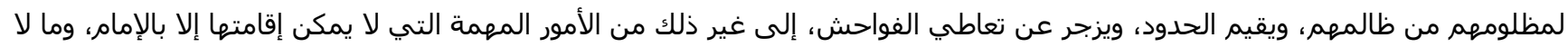
يتم الواجب إلا به فهو واجب الحبر ذلب من

“...dan sungguh Al Qurthubi dan yang lain berdalil berdasarkan ayat ini atas wajibnya mengangkat khalifah untuk menyelesaikan perselisihan yang terjadi diantara manusia, memutuskan pertentangan mereka, menolong pihak yang didzalimi dari yang mendzalimi, menegakkan had-had, dan mengenyahkan kerusakan, serta urusan-urusan penting lain yang tidak mungkin ditegakkan tersebut kecuali dengan adanya seorang imam, dan ما لايتم الواجب الا به فهو واجب (apabila suatu kewajiban tidak akan sempurna kecuali dengan suatu maka sesuatu tersebut menjadi wajib pula)". [ Imam al-Hafidz Abu Al-fida' Ismail Ibn Katsir, Tafsirul Qur'anil Adzim, juz 1 hal 221)].

Imam Al Qurthubi ketika menafsirkan Surah Al Baqarah : 30 berkata

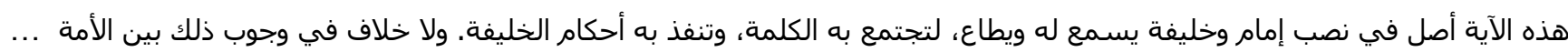

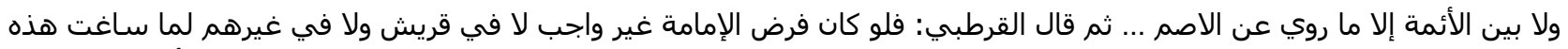

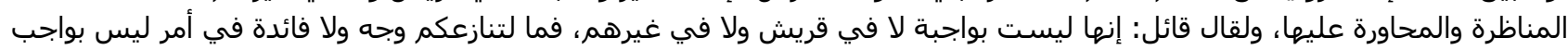

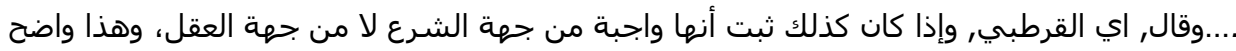

“...ayat ini dalil paling asal dalam persoalan pengangkatan imam dan khalifah yang wajib didengar dan dita'ati, untuk menyatukan pendapat serta melaksanakan, hukum-hukum khalifah. Tidak ada perbadaan tentang wajibnya hal tersebut diantara umat, tidak pula diantara para imam kecuali apa yang diriwayatkan dari Al-A'sham ...Selanjutnya beliau berkata: “...Maka kalau seandainya keharusan adanya imam itu tidak wajib baik untuk golongan Quraisy maupun untuk yang lain lalu mengapa terjadi diskusi dan perdebatan tentang Imamah. Maka sungguh orang akan berkata: bahwa sesungguhnya imamah itu bukanlah suatu yang diwajibkan baik untuk golongan Quraisy maupun yang lain, lalu untuk apa kalian semua berselisih untuk suatu hal yang tidak ada faedahnya atas suatu hal yang tidak wajib”. Kemudian beliau menegaskan: "...Dengan demikian maka (telah) menjadi ketetapan bahwa imamah itu wajib berdasarkan syara' bukan akal. Dan masalah ini jelas sekali”. [Al Imam Muhammad bin Ahmad bin Abu Bakar bin Farah Al Qurthubi, Al Jaami' li Ahkamil Qur'an, juz 1 hal 264-265].

Imam Umar bin Ali bin Adil Al Hanbali Ad Dimasyqi, yang dikenal dengan Ibnu Adil, ketika menjelaskan firman Allah Ta'ala surah Al Baqarah ayat 30 berkata:

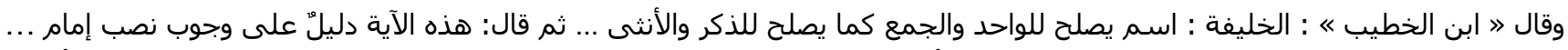

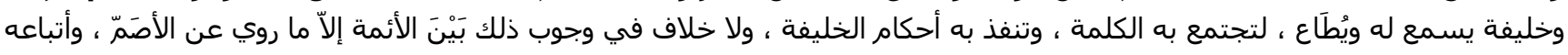
...

“... dan Ibn Al Khatib berkata, "Khalifah itu isim yang cocok baik untuk tunggal maupun plural sebagaimana cocoknya untuk lakilaki dan wanita. Kemudian beliau berkata, "....Ayat ini adalah dalil wajibnya mengangkat Imam dan khalifah yang didengar dan dita'ati, untuk menyatukan pendapat, serta untuk melaksanakan hukum-hukum tentang khalifah. Tidak ada perbedaan tentang wajibnya hal tersebut diantara para imam kecuali apa yang diriwayatkan dari Al-A'sham dan orang yang mengikuti dia..." [Imam Umar bin Ali bin Adil Al Hanbali Ad Dimasyqi, Tafsirul Lubab fii 'Ulumil Kitab, juz 1 hal 204].

Berkata Imam Abu al Hasan Al Mardawiy Al Hanbali dalam kitab Al Inshaaf:

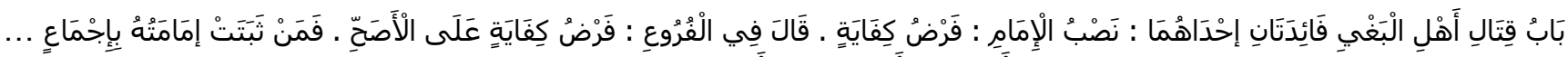

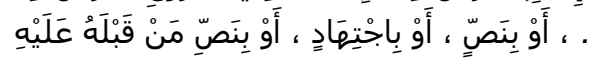

“...bab memerangi orang yang Bughat, terdapat dua faedah. Pertama, mengangkat imam itu adalah fardhu kifayah. Berkata di dalam Al Furuu', “..Fardhu kifayahlah yang paling tepat...."[Imam Abul Hasan Ali bin Sulaiman Al Mardawi Al Hanbali, Al-inshaaf fii Ma'rifatir Rajih minal Khilaf ala Madzhabil Imam Ahmad bin Hanbal, juz 16 hal. 60 dan 459].

Imam Al Bahuti Al Hanafi berkata:

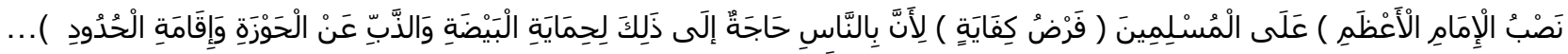

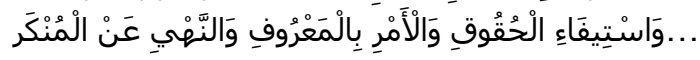

“...(mengangkat Imam yang agung itu) atas kaum Muslimin (adalah fardhu kifayah). Karena manusia membutuhkan hal tersebut untuk menjaga kemurnian (agama), menjaga konsistensi (agama), penegakan had, penunaian hak serta amar ma'ruf dan nahi munkar...". [Imam Mansur bin Yunus bin Idris Al Bahuti Al Hanafi, Kasyful Qanaa' 'an Matnil Iqnaa', juz 21 hal. 61]

Sedangkan dalam kitab Mathaalib Ulin Nuha fii Syarhi Ghayatil Muntaha dinyatakan: 


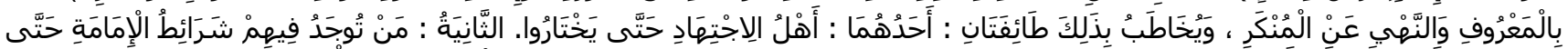

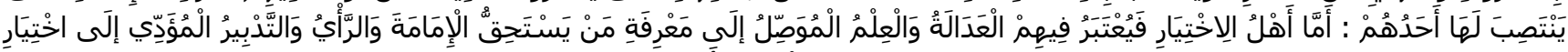

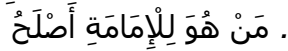

“...(dan mengangkat imam itu adalah fardhu kifayah) karena manusia memang membutuhkan hal tersebut untuk menjaga kemurnian (agama), memelihara konsitensi (agama), menegakkan had, menunaikan hak-hak, dan amar makruf serta nahi munkar". [Al 'Allamah Asy Syeikh Musthafa bin Sa'ad bin Abduh As Suyuthi Ad Dimasyqi Al Hanbali, Mathalibu Ulin Nuha fii Syarhi Ghayatil Muntaha, juz 18 hal. 381 ].

Berkata Shahiibu Al Husuun Al-Hamidiyyah, Syeikh Sayyid Husain Affandi:

$$
\text { ... اعلم أنه يجب على المسلمين شـرعا نصب إمام يقوم باقامة الحدود وسـد الثغور وتجهيز الجيش }
$$

"Ketahuilah, sesungguhnya wajib atas kaum Muslim secara syar'iy, mengangkat seorang Imam yang menegakkan had, memelihara perbatasan (negara), menyiapkan pasukan..".[Sayyid Husain Afandi, Al-Husun Al-Hamidiyyah li Al Muhafadzah 'ala Al-Aqaa'id Al-Islamiyyah, hal 189].

\section{METODE MEWUJUDKAN SISTEM PEMERINTAHAN ISLAM}

Siapapun yang melakukan penelaahan mendalam terhadap sirah Nabi Muhammad saw. akan menemukan bahwa beliau menempuh tiga tahapan dalam mewujudkan pemerintahan Islam di Madinah.

\subsection{Tahap Pertama: Kaderisasi (Tatsqif).}

Sejak beliau mendapatkan wahyu, beliau diperintahkan untuk menyampaikannya kepada masyarakat. Misalnya, ketika Allah SWT menurunkan QS al-Muddatsir ayat 1-2, bersegeralah sang Nabi terakhir itu mengajak masyarakat untuk memeluk Islam. Beliau menyampaikan Islam kepada istrinya, Khadijah ra. Kemudian, disampaikan pula kepada sepupunya Ali bin Abi Thalib ra., maulanya Zaid, sahabat beliau Abu Bakar ash-Shiddiq ra., dan masyarakat secara umum.

Di sinilah Nabi saw. melakukan dua hal. Pertama: pembinaan akidah dan syariah hingga terbentuk para kader berkepribadian Islam. Kedua: pengorganisasian Sahabat sehingga membentuk kelompok dakwah yang secara solid dan berjamaah bergerak di tengah masyarakat. Bukan hanya Nabi saw. seorang diri yang melakukan pembinaan, para Sahabat lain pun mencari dan membina orang yang baru masuk Islam. Sebagai contoh, beliau pernah meminta Khubbab bin al-Arts untuk mengajarkan al-Quran kepada Zaenab binti al-Khaththab dan suaminya, Said, di rumahnya.

Bila dilihat dari kacamata modern apa yang dilakukan oleh Rasulullah saw ini merupakan pembinaan intensif (tatsqif murakkaz). Pembinaan intensif ini dilakukan untuk membentuk kader yang berkepribadian Islam dan siap berjuang.

\subsection{Tahap Kedua: Membangun Kesadaran Umat (Tafa'ul Ma'al Ummah).}

Tidak semua anggota masyarakat dapat dan mau menjadi kader dakwah. Karenanya, perlu ada penumbuhan kesadaran kolektif umat bagi kalangan tersebut. Pegiatnya adalah para kader dakwah yang terorganisir rapi yang terbina dalam pembinaan intensif tersebut. Untuk menumbuhkan kesadaran itu perlu ditempuh beberapa hal secara bersamaan, yaitu:

\subsubsection{Pergolakan Pemikiran (ash-Shira' al-Fikri).}

Rasulullah saw. senantiasa melakukan pergolakan pemikiran terhadap gagasan/ide/pandangan yang sifatnya tetap. Ini umumnya merupakan pemahaman (mafahim), tolok ukur (maqayis) atau keyakinan (qana'at). Misalnya, beliau menyuarakan secara lantang realitas tuhan kaum kafir seperti ayat Allah SWT (yang artinya): Sesungguhnya kalian dan apa (berhala) yang kalian sembah adalah umpan neraka Jahanam (QS al-Anbiya' [21]: 98). Beliau juga menentang sikap hidup kafir Quraisy yang merasa aib bila memiliki bayi perempuan hingga harus membunuhnya.Untuk saat ini, segala gagasan/ide/pandangan yang merupakan akidah kufur harus ditentang dan dijelaskan kebatilannya. Misalnya, sekularisme, pluralisme dan liberalisme merupakan ide yang harus di tentang. Begitu juga gagasan cabang yang lahir darinya seperti demokrasi, hak asasi manusia, kesetaraan gender, dll.

\subsubsection{Perjuangan Politik (al-kifah as-siyasi).}

Aktivitas al-kifah as-siyasi merupakan aktivitas yang ditujukan untuk menyikapi realitas politik kekinian, yang terjadi pada saat tertentu. Pada zaman Rasulullah saw. pernah ada suatu realitas: mengurangi timbangan sudah menjadi kebiasaan. Untuk menyikapi hal tersebut, Allah SWT menurunkan QS al-Muthafifin yang diserukan oleh Rasulullah saw. di tengah masyarakat. Pada saat kaum kafir meminta agar Nabi saw. menunjukkan mukjizat seperti para nabi terdahulu dan meminta agar Nabi saw. berdoa hingga harga yang melambung tinggi menjadi turun, dijawab dengan telak dalam QS al-A'raf [7] ayat 188. Begitu juga kebiasaan mereka menjerumuskan budak wanita dalam pelacuran (semacam trafficking sekarang) disikapi oleh Nabi saw. dengan menyampaikan QS an-Nur [24] ayat 33. Masih banyak peristiwa lain.

\subsubsection{Membongkar rencana jahat kaum kafir (kasyfal-khuthath).}

Rasulullah saw. sering menyampaikan wahyu terkait rencana jahat kaum kafir. Sebagai contoh, membongkar rencana tokoh Quraisy (seperti Abu Jahal, Abu Sufyan, Umayyah ibn Khalaf dan Walid bin Mughirah) yang berdiskusi di pusat kajian strategis mereka, Darun Nadwah, dengan memberikan cap negatif pada diri Rasulullah saw.; membongkar persekong-kolan kaum kafir dengan kaum munafik. Allah SWT membongkar rencana jahat ini dalam QS al-Mudatstsir [74] ayat 18-26. 


\subsubsection{Penting juga untuk melakukan advokasi bagi kepentingan umat (tabanni mashalih ummah).}

Caranya, dengan melakukan advokasi bagi kepentingan umat. Misalnya, ketika ada pihak yang ingin melakukan yudisial review UU Penodaan Agama, maka perlu dilakukan perlawanan dengan menjadi pihak terkait dalam sidang di Mahkamah Konstitusi. Ketika terjadi malpraktik maka dapat dilakukan upaya pembelaan terhadap korban. Dilakukanlah advokasi terhadap pihak terkait, termasuk penguasa. Disampaikan solusi menurut Islam. Hal ini dilakukan sedemikian rupa sampai hasil yang diinginkan.

Jika semua aktivitas itu dilakukan secara intensif dan masif maka insya Allah dengan izin Allah SWT taraf berpikir umat akan makin meningkat. Pembelaan dan dukungan terhadap syariah dan Khilafah beserta para pejuangnya akan menggelontor. Sebab, di mata umat makin tampak siapa sebenarnya yang berjuang untuk membebaskan mereka dari penjajahan.

\subsection{Tahap Tiga: Istilam al-Hukmi dengan Dukungan Ahlun Nushrah.}

Pada saat kehendak dominan masyarakat menghendaki syariah dan Khilafah, maka masyarakat bersama dengan kelompok pejuang syariah dan Khilafah akan menuntut penguasa agar menegakkan Khilafah atau mundur seraya menyerahkan kepemimpinan kepada mereka. Umat tidak percaya lagi kepada penguasa maupun wakil mereka. Terjadilah kevakuman kekuasaan. Mereka yang terdiri dari tokoh-tokoh berbagai daerah dari berbagai kalangan dan organisasi membentuk semacam ahlul halli wal 'aqdi untuk membaiat khalifah. Bila penguasa secara sukarela menyerahkan kekuasaan atas dasar kesadaran bahwa mereka sudah delegitimasi, tidak lagi dipercaya oleh rakyat, apalagi mereka berubah menjadi mendukung tuntutan masyarakat itu, maka ketika itu terjadilah penyerahan kekuasaan dari rakyat kepada penguasa baru (istilam al-hukmi). Mereka hanya tinggal mengumumkan ke publik, "Kami mundur dari kekuasaan ini karena sudah tidak lagi dipercaya rakyat sebagai pemilik kekuasaan tersebut."

Namun sebaliknya, bila mereka tak mau melepaskan kekuasaan kufurnya, lalu menghadapi rakyat sebagai pemilik kekuasaan dengan kekerasan maka di sinilah pentingnya dukungan pemilik kekuatan (ahlul quwwah, ahlun nushrah) terhadap dakwah. Oleh sebab itu, sejak awal perlu adanya dukungan ahlun nushrah.

Mereka yang masuk ke dalam ahlun nushrah adalah setiap pemilik kekuatan, termasuk militer. Dengan adanya dukungan ahlun nushrah penyerahan kekuasaan akan terjadi dengan damai. Begitulah yang dialami oleh Nabi saw. saat menegakkan pemerintahan di Madinah. Cara untuk meraih dukungan ahlun nushrah tidak lain dengan mendatangi dan mendakwahi mereka.

Ketika istilam al-hukmi telah terjadi, maka di tengah penguasa yang telah kehilangan legitimasinya, khalifah dengan dukungan rakyat mengumumkan tegaknya Khilafah. Penyelesaian peralihan kekuasaan dilakukan dalam tempo sesingkat-singkatnya sesuai dengan realitas politik waktu itu. Dengan teknik seperti ini penegakkan Khilafah akan berjalan secara alami. Wallahu a'lam

\section{KESIMPULAN}

Khilafah, terang benderang sebagai bagian dari ajaran Islam yang mulia, memuliakan mereka yang mengemban dan memperjuangkannya, seterang mentari terbit tak terhalang awan bagi ia yang teguh meniti jalan Rasul-Nya. Secara praktis, penegakkan konsep khas kepemimpinan Islam ini sebagaimana ditunjukkan oleh sunnah Rasulullah Saw, yang menegakkan institusi politik Islam berpusat di Madinah al-Munawwarah, diteruskan oleh para sahabat al-khulafâ' al-râsyidûn pada periode yang disebut Rasulullah Saw dalam hadits hasan riwayat Imam Ahmad, sebagai periode al-khilâfah 'alâ minhâj al-nubuwwah. Ditegaskan para ulama dalam turats mereka yang menguraikan kewajiban menegakkan institusi Khilafah ini dalam kehidupan, sebagai ajaran Rasulullah Saw dan disepakati para sahabat dengan konsensus (ijma') mereka.

Maka tak ada jalan lain bagi kita yang mengaku mencintai mereka, kecuali berjuang merealisasikan kembali kepemimpinan Islam ini, sebagai salah satu bagian dari pesan mendalam Rasulullah Saw, dari Al-'Irbadh bin Sariyah ia berkata: Rasulullah Saw bersabda:

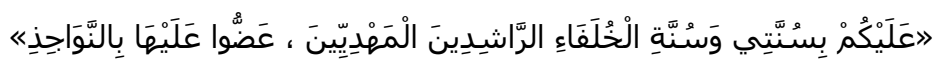

"Hendaklah kalian berdiri di atas sunnahku, dan sunnah para khalifah al-rasyidin al-mahdiyyin (khalifah empat yang mendapatkan petunjuk), gigitlah oleh kalian hal tersebut) dengan geraham yang kuat." (HR. Ahmad, Ibn Majah, Al-Hakim, AlBaihaqi) 50

\section{REFERENSI}

Adlan, A. (2015). Tahkîm al-Syarî'ah, Al-Tadarruj Lâ al-Taswîf. Majallat al-Bayân

al-Atsir, M.A.S.M.I. (1971). Jâmi' al-Ushûl fî Ahâdîts al-Rasûl. Maktabat Dâr al-Bayân.

Al-Jaza'iri, J.A.B. (2003). Aysar at-Tafâsîr li Kalâm al-'Ulya al-Kabîr. Madinah: Maktabah al-'Ulûm wa al-Hikam. al-Manawi, A. (1937). Faydh al-Qadîr Syarh al-Jâmi' al-Shaghîr, Mesir: Al-Maktabah al-Tijâriyyah al-Kubrâ'. al-Naisaburi, N. Gharâ'ib al-Qur'ân wa Raghâ'ib al-Furqân, Dâr al-Kutub al-'Ilmiyyah al-Nawawi, S. (1998). Riyâdh al-Shalihîn. Beirut: Mu'assasat al-Risâlah. al-Qarafi, A.A.S.A. (1998). Al-Furûq: Anwâr al-Burûq fî Anwâ'i al-Furûq. Beirut: Dâr al-Kutub al-'Ilmiyyah al-Qari, M.A. Mirqât al-Mafâtîh Syarh Misykât al-Mashâbîh, juz VI, hlm. 2391. al-Qari, S.M.H.M. Mirqât al-Mafâtîh Syarh Misykât al-Mashâbîh, juz VI, hlm. 2391. al-Rasythah, A.K. Al-Taysîr fî Ushûl Al-Tafsîr: Sûrat al-Baqarah. al-Rasythah, A.K.A. Al-Taysîr fî Ushûl al-Tafsîr: Sûrat al-Baqarah, hlm. 107-108.

\footnotetext{
${ }^{50}$ HR. Ahmad dalam Musnad-nya (no. 17184), Syaikh Syu'aib al-Arna'uth mengomentari: "Hadits shahih dan para perawinya tsiqah.”; Ibn Majah dalam Sunan-nya (no. 42), Syaikh Syu'aib al-Arna'uth mengomentari: "Hadits shahih dengan banyak jalan periwayatan dan syawahid (riwayat-riwayat pendukungnya). "; Al-Hakim dalam Al-Mustadrak (no. 329), al-Hakim berkata: "Ini hadits shahih, tidak mengandung satupun cacat." ditegaskan senada oleh al-Hafizh al-Dzahabi; Al-Baihaqi dalam Syu'ab al-Iman (no. 7516).
} 
JKPIs, Vol. 1 No. 1, 2018 | 49

al-Shan'ani, I.K. (2011). Al-Tanwiir Syarh al-Jâmi' al-Shaghiir, Ed: Dr. Muhammad Ishaq. Riyadh: Maktabat Dâr alSalâm.

al-Subki, T.A.W. Al-Asybâh wa al-Nazhâ'ir. Dâr al-Kutub al-Ilmiyyah.

al-Tsa'labi, I. (2002). Al-Kasyf wa al-Bayân 'an Tafsîr al-Qur'ân, Beirut: Dâr Ihyâ' at-Turâts al-'Arabi.

At-Thabari. (1992). Jâmi' al-Bayân fî Ta'wîl al-Qur'ân, juz XVII.

Ibrahim, A.Q.T. (1953). Nizhâm Al-Islâm. Beirut: Dar al-Ummah.

Ji, M.R.Q. (1988). Mu'jam Lughat al-Fuqahâ'. Beirut: Dâr al-Nafâ'is.

Ji, R.Q. (1988). Mu'jam Lughat al-Fuqahâ'. Beirut: Dâr al-Nafâ'is.

Tahrir, H. (2004). Min Muqawwimât al-Nafsiyyah al-Islâmiyyah. Beirut: Dâr al-Ummah. 